\title{
PROSPEK PENGELOLAAN SUMBER DAYA PERIKANAN BERBASIS EKOSISTEM: STUDI EMPIRIS DI KARIMUNJAWA *
}

\author{
Indah Susilowati \\ Fakultas Ekonomika dan Bisnis Universitas Diponegoro \\ Jalan Prof. Soedarto, S.H. Semarang 50275, Indonesia \\ Email: indah-susilowati@rocketmail.com
}

Diterima 3 Februari 2013 / Disetujui 6 Mei 2013

\begin{abstract}
The objectives of the study are: to compare the model of fisheries management with conventional versus new paradigm; to explore the prospect of new fisheries management model; to formulate the initial strategy of fisheries management model using EBFM. The ecosystem of Karimunjawa is selected as the pilot project of this research. The competent 25 keypersons were selected using purposive quoted sampling for interview. Descriptive statistics, meta-analysis and AHP were employed to analize the data. The results showed that the conventional fisheries management models were rather ineffective to answer the current situation of fisheries resource. We need facing out to find a suitable approach of fisheries management model. One of the proposed new paradigm is EBFM. This model indicates has a good prospect to manage the fisheries resource in the study area. This study suggests that EBFM model should be under-tried out. If it is acceptable, then the model can be implemented for other region.
\end{abstract}

Keywords: fisheries, management, ecosystem-based, institutional, Karimunjawa, Indonesia

\begin{abstract}
Abstrak: Penelitian ini bertujuan; pertama, membandingkan model pengelolaan sumber daya perikanan dengan versi konvensional dan yang berparadigma baru; kedua, mengeksplorasi tingkat keberhasilan model pengelolaan sumberdaya perikanan dengan paradigma baru; dan ketiga menyusun strategi pengelolaan sumberdaya perikanan berbasis ekosistem (EBFM). Ekosistem Karimunjawa yang merupakan wilayah kepulauan yang dapat diambil menjadi pilot project. Tokoh kunci sebanyak 25 orang yang diambil secara purposive quoted sampling. Deskriptif statistik dipakai untuk menganalisis data penelitian dan juga dilengkapi dengan metode Meta-Analysis dan Analysis Hierarchy Proccess. Hasil penelitian menunjukkan bahwa model pengelolaan secara konvensional masih belum berhasil dalam mengelola sumberdaya. Sedangkan, pengelolaan sumberdaya perikanan berbasis ekosistem memberikan indikasi yang prospektif. Untuk itu disarankan perlu diuji-coba implementasinya. Bila model EBFM yang diusulkan ini telah lolos uji maka kerangka implementasi EBFM ini diharapkan dapat diadopsi oleh daerah lain di Indonesia untuk mengelola sumber daya perikanannya.
\end{abstract}

Kata kunci: perikanan, pengelolaan, berbasis-ekosistem, kelembagaan, Karimunjawa, Indonesia

\section{PENDAHULUAN}

Fenomena tragedy of the common sering melekat pada pemanfaatan sumberdaya perikanan sebagai sumberdaya milik umum (common property resource) yang mempunyai sifat open access, yai-

* Tulisan ini merupakan bagian dari hasil penelitian payung skim Hibah Kompetensi TA.2012. DP2M-Ditjen DIKTI. tu: terbuka bagi umum untuk memanfaatkanya. Karakteristik ini sering menimbulkan dampak negatif pada kelestarian sumberdaya perikanan.

Secara umum, model-model pengelolaan perikanan konvensional yang dikembangkan selama ini didasarkan atas positivistic science yang berasumsi bahwa ekosistem alam ini dapat diprediksi dan dikontrol. Dalam kenyata- 
annya, asumsi ini sangat sulit untuk dipenuhi. Hal ini dikarenakan kemampuan manusia untuk memprediksi perilaku ekosistem alam terbatas, sehingga gagal dalam mengadopsi perilaku ekosistem dalam modelnya. Alasan lainnya adalah model-model pengelolaan perikanan konvensional sebagian besar dikembangkan untuk spesies tunggal pada perikanan industri di belahan bumi utara bagian barat, sehingga tidak cocok diterapkan pada perikanan daerah tropis yang berskala kecil dan bersifat multigear-multispecies. Perbedaan skala, sistem penangkapan ikan dan ekosistem perairan, menyebabkan model-model konvensional tidak mampu untuk menerangkan kompleksitas perikanan daerah tropis.

Sebagai suatu ekosistem, wilayah pesisir dan laut tidak hanya menyediakan sumberdaya perikanan, tetapi terdapat pula sumberdaya alam hayati lainnya seperti mangrove, terumbu karang dan rumput laut; dan sumberdaya alam nir-hayati, di antaranya sumberdaya mineral, minyak bumi dan gas alam. Dengan demikian, pembahasan tentang pengelolaan sumberdaya perikanan tidak terlepas dari wilayah pesisir dan laut serta ekosistem terkait yang ada di dalamnya, sehingga analisis ekosistem menjadi elemen yang penting dalam pengelolaan sumberdaya perikanan (Trites et al. 1999, Bundy dan Pauly 2001, Gasalla dan Rossi-Wongtschowski 2004, Coll et al. 2007). Pendekatan ekosistem ini merupakan salah satu bentuk pengelolaan sumberdaya yang mempertimbangkan perilaku, karakteristik atau sifat dari alam yang selama ini harus dinomor-duakan setelah kepentingan manusianya dikedepankan. Oleh karena itu, kita perlu melakukan facing-out kepada model pengelolaan sumberdaya perikanan berbasis ekosistem, yang dikenal sebagai: Ecosystem based Fisheries Management (EBFM). Dalam EBFM, pengelolaan sumberdaya perikanan mencakup keseluruhan ekosistem termasuk aspek stakeholders dan dampak yang terjadi pada setiap sektor yang terkait pada perikanan.

Peran sumberdaya perikanan tidak diragukan lagi sumbangannya bagi bangsa dan negara Indonesia. Selain sebagai sumber penghidupan masyarakat untuk lapangan kerja maka juga menjadi sumber nutrisi hewani dan penghasil devisa negara. Namun, pada kenyataanya potensi sumberdaya perikanan Indonesia belum bisa dikelola dan dimanfaatkan secara optimal dan arif. Hal ini dikarenakan pengelolaan sumberdaya perikanan belum memadai sehingga masih menimbulkan banyak permasalahan dalam pengembangan sektor ini. Produksi perikanan yang tinggi, tidak diimbangi dengan nilai ekspor yang tinggi adalah salah satu contoh nyata bahwa perikanan belum bisa dimanfaatkan dan dikelola secara optimal serta arif ${ }^{1}$.

Pengelolaan perikanan di Indonesia memerlukan restrukturisasi agar sumberdaya yang ada bisa dimanfaatkan secara optimal dan arif. Sistem pemerintahan desentralisasi yang dianut Indonesia memberikan implikasi bahwa setiap daerah memiliki kewenangan untuk mengelola daerahnya masing-masing ${ }^{2}$. Kewenangan pemerintah ini mencakup pengelolaan kekayaan alam, baik yang berupa sumberdaya di daratan maupun di lautan. Adapun urusan pengelolaan dalam kelautan yang didesentralisasikan meliputi eksplorasi, konservasi dan pengelolaan kekayaan laut, tata ruang dan administrasi serta penegakan hukum. Penelitian ini diharapkan mampu merumuskan rekayasa model pengelolaan sumberdaya perikanan dengan pendekatan Ecosystem-based Fisheries Management (EBFM) di Indonesia, dengan studi kasus di Karimunjawa sebagai representasi wilayah pesisir utara Provinsi Jawa Tengah. Ini dalam rangka mencari bentuk pengelolaan sumberdaya perikanan yang cocok.

\section{METODE PENELITIAN}

Materi dan Metode. EBFM didefinisikan sebagai upaya pengelolaan perikanan yang mencakup pengelolaan fisik, biologi, ekonomi dan interaksi sosial yang berada dalam satu ekosistem, untuk mencapai beberapa tujuan sosial Marasco et. al (2007). Dalam konteks ini, ekosistem adalah kesatuan unit yang meliputi keseluruhan faktor biotik (habitat, makanan,

Selama ini komoditas perikanan yang diekspor sebagian besar berupa ikan segar atau beku dengan nilai tambah yang kecil (DKP,2008)

UU No.27 Tahun 2007 tentang Pengelolaan Wilayah Pesisir dan Pulau-Pulau Kecil 


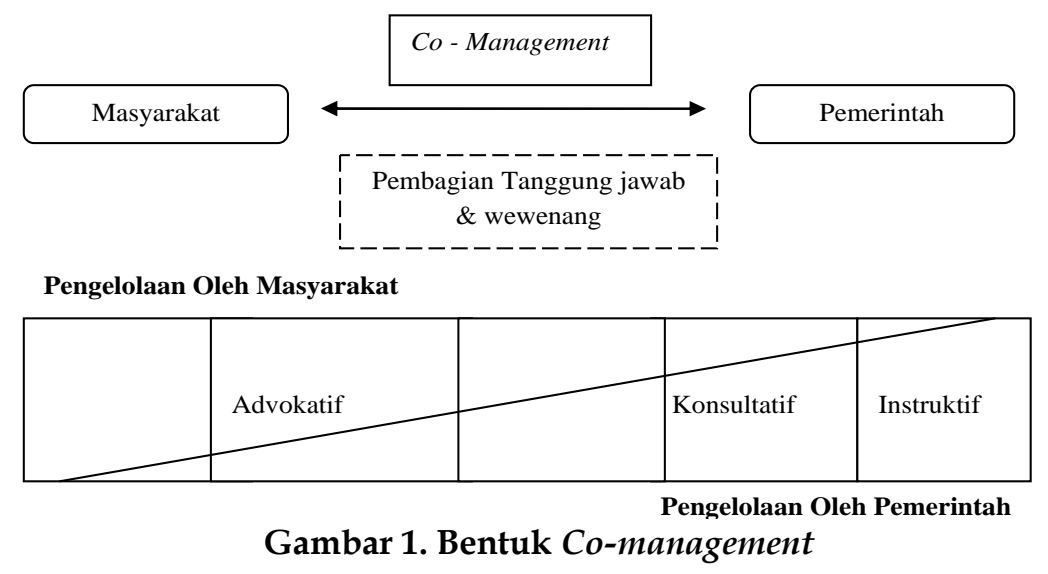

dan lain lain) dan faktor abiotik yang mempengaruhinya. Sehingga EBFM bertujuan melindungi ekosistem terhadap perubahan komponen ekologi, sosial atau ekonomi untuk melindungi spesies yang hampir punah, habitat penting dan bycatch (Pope et al. 2000, Pikitch et al. 2004). Sampai saat ini tidak ada metodologi yang fixed untuk memformulasikan EBFM, hal ini juga dibenarkan oleh Marasco et al. (2007). Meskipun demikian, pelaksanaan EBFM mempunyai manfaat yang lebih besar dibanding resiko nya (Pikitch et al. 2004).

Pengelolaan Sumberdaya Perikanan Berbasis Masyarakat (CBFM) relatif efektif untuk mengatasi konflik, terutama pada pengelolaan dan kontrol yang dilakukan oleh masyarakat atas sumber produktif. Sedangkan, Pomeroy dan Williams (1994) menjelaskan bahwa konsep co-management adalah konsep pengelolaan yang mampu menampung kepentingan masyarakat maupun kepentingan pengguna lainnya. comanagement didefinisikan sebagai pembagian tanggung jawab dan wewenang antara pemerintah dengan pengguna sumberdaya alam lokal (masyarakat) dalam pengelolaan sumberdaya alam seperti perikanan, terumbu karang, mangrove dan lain sebagainya. Dalam co-management, masyarakat lokal merupakan partner penting bersama-sama dengan pemerintah dan stakeholders lainnya dalam pengelolaan sumberdaya alam di suatu kawasan. Jadi, dalam comanagement bentuk pengelolaan sumberdaya alam berupa gabungan dari dua pendekatan utama yaitu pengelolaan yang dilakukan oleh pemerintah (Goverment Centralized Management) dan pengelolaan yang dilakukan oleh masyarakat (Community Based Management), lihat Gam- bar 1. Untuk Community Based Management, hirarki yang tertinggi adalah kontrol yang ketat dari masyarakat dan koordinasi antararea yang dilakukan oleh masyarakat itu sendiri.

Arah dan tujuan tujuan penelitian ini dapat dilihat peta jalan (roadmap) yang dirangkum dalam Gambar 2.

Penentuan sampel diambil secara terkuota (quoted purposive sampling) terhadap 25 responden dari unsur: (1) Akademisi: ahli Perikanan, ahli Biodiversity, ahli Aquaculture (5 orang); (2) Pebisnis/Swasta: LSM dan Pengusaha yang berada di kawasan ekosistem Karimunjawa memanfaatkan/berhubungan langsung dengan sektor perikanan dan kelautan seperti pengusaha pengelola kawasan wisata di Karimunjawa, UMKM pengolah ikan berskala menengah-besar, pengusaha rumput laut, dan sebagainya (5 orang); (3) Pemerintah: UPT Departemen Kehutanan Balai Nasional Taman Karimunjawa, Dinas Perikanan dan Kelautan Provinsi Jawa Tengah, Dinas Perikanan Kabupaten terkait, Bappeda Provinsi, Kabupaten Jepara dan PNS (7 orang); (4) Komunitas: Masyarakat setempat, Nelayan, Pengolah Ikan, dan sebagainya (8 orang).

Data kerat lintang (cross-sectional) dikumpulkan melalui wawancara dengan panduan kuesioner sebagai data primer. Data sekunder diperoleh melalui studi pustaka dan dokumentasi dari dinas/ institusi terkait, misal: Badan Pusat Statistik, Balai Nasional Taman Karimunjawa, Dinas Kelautan dan Perikanan Provinsi Jawa Tengah, Dinas Kelautan dan Perikanan Kabupaten Jepara dan Pati. Pendekatan analisis penelitian ini adalah metode campuran antara kualitatif dan kuantitatif (mixed-method) seperti 


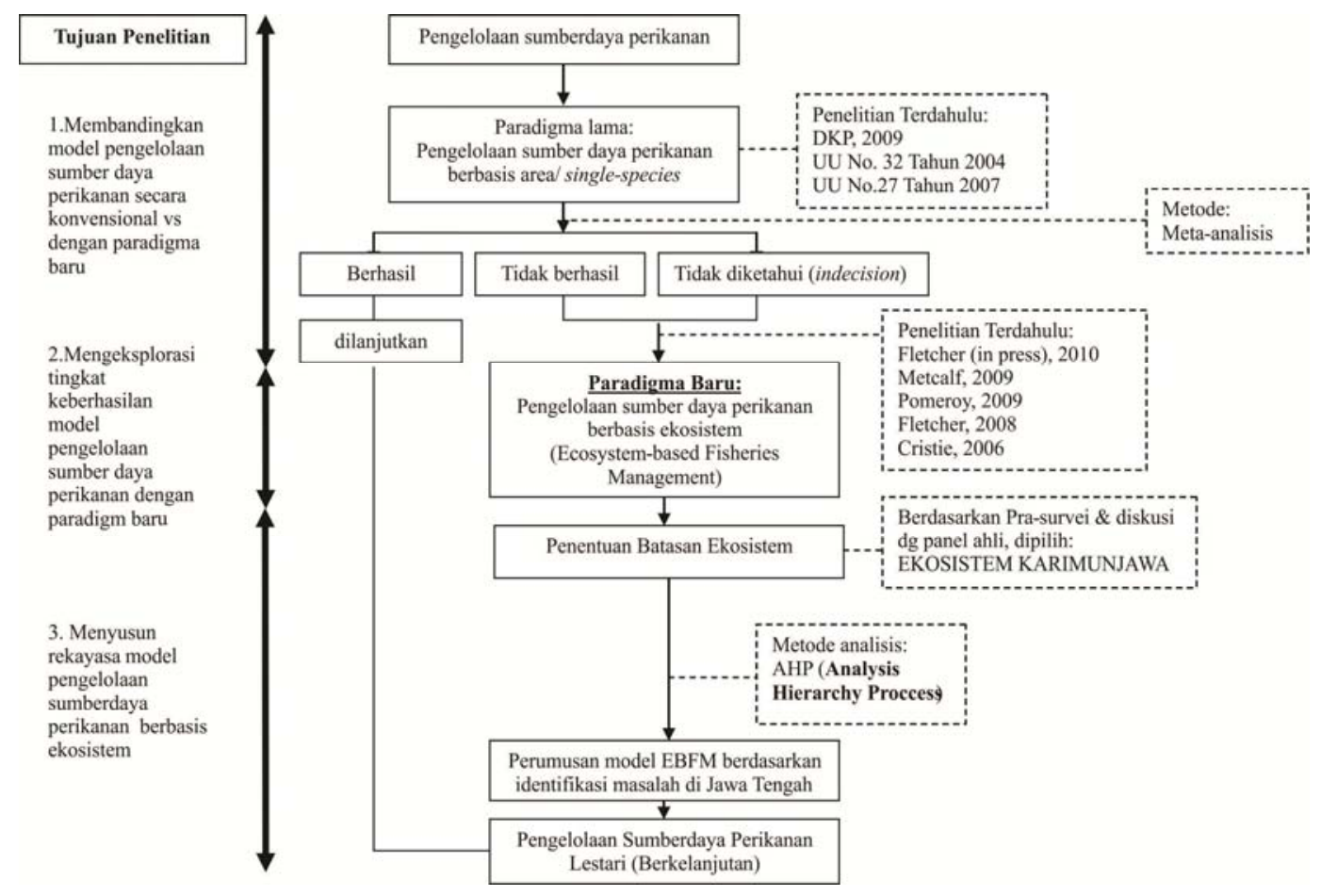

Gambar 2. Peta Jalan (Roadmap)

yang dipakai oleh Susilowati dan Sucihatiningsih (2012) dengan mengaplikasikan statistik deskriptif, Meta-Analysis dan AHP (Analysis Hierarchy Proccess). Meta-Analysis adalah metode dengan cara me-review laporan, jurnal dan bahan lain yang terkait untuk menjawab suatu permasalahan (Pomeroy et. al, 1994). Metode ini digunakan untuk menjawab tujuan penelitian yang pertama dan kedua, yaitu mengevaluasi model pengelolaan perikanan secara konvensional versus dengan paradigma baru dan mengeksplorasi tingkat keberhasilan model pengelolaan perikanan dengan paradigma baru. Sedangkan metode AHP (Saaty, 1993) dipakai untuk memberikan bukti kuantitatif dari penyusunan strategi pengelolaan sumberdaya perikanan yang berbasis pada ekosistem.

\section{HASIL DAN PEMBAHASAN}

\section{Evaluasi Tingkat Keberhasilan Beberapa Model Manajemen Perikanan}

Metode penilaian yang digunakan untuk mengevaluasi tingkat keberhasilan model pengelolaan adalah metode yang diadopsi dari RAFMS (Rapid Appraisal of Fisheries Management System), yaitu metode yang digunakan untuk memahami bagaimana peraturan mempengaruhi perilaku dan keluaran (outcomes) dengan menggunakan sumberdaya perikanan; dan Rapfish (Rapid Appraisal for Fisheries), yaitu sebuah teknik penilaian yang multidisipilin untuk mengevaluasi status keberlanjutan perikanan (Pitcher dan David Preikshot, 2001). Penilaian ini dilakukan oleh panel ahli sumberdaya perikanan yang terdiri dari empat panel ahli.

Evaluasi dilakukan pada tiga (3) bentuk model pengelolaan perikanan dan telah dilaksanakan di Indonesia, yaitu Traditional Based Fisheries Management, Community Based Fisheries Management dan Co-Management. Selain itu, dilakukan pula prediksi evaluasi apabila diterapkan bentuk model pengelolaan berbasis ekosistem.

(1) Hasil Analisis RAFMS. Gambaran umum dari grafik yang didapat menggunakan metode RAFMS dari panel ahli, dapat diketahui bahwa prediksi menggunakan manajemen perikanan berbasis ekosistem lebih baik dibanding pengelolaan model lainnya. Hal ini dapat diketahui melalui pembuktian jawaban yang didapat dari panel ahli sebanyak empat panel ahli dengan jawaban "good" yang hampir ada 


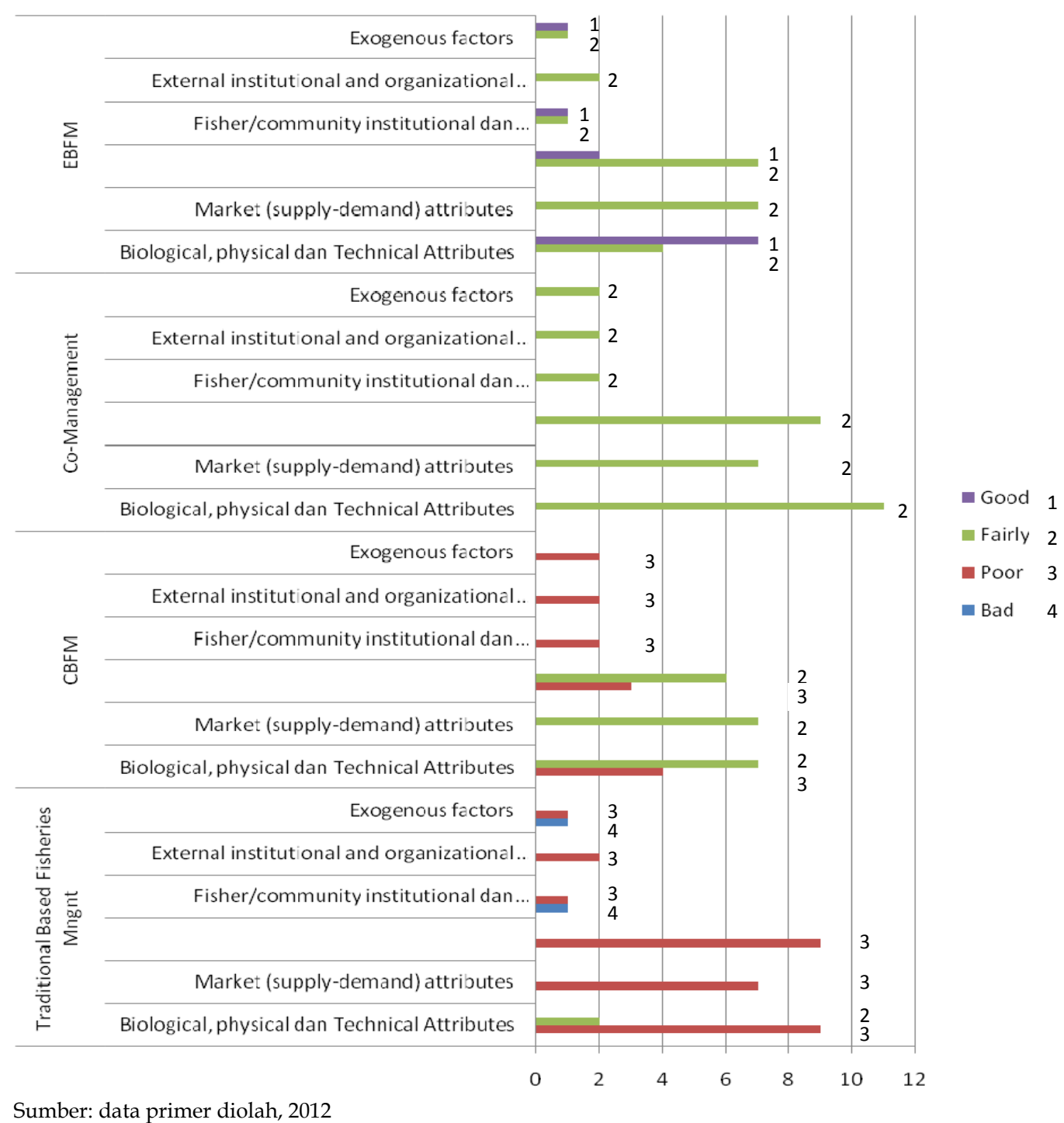

Sumber: data primer diolah, 2012

Gambar 3. Hasil Evaluasi Model Pengelolaan Perikanan dengan Metode RAFMS

pada tiap atribut, sedangkan pengelolaan yang kurang baik terdapat pada model manajemen perikanan berbasis tradisional. Pada model ini pengelolaan perikanan terjadi apabila sudah ada masalah, kondisi "poor" mendominasi pada model ini sedangkan atribut lain pada model ini terdapatnya juga kondisi " $b a d "$ ". Untuk model pengelolaan "Community Base Fisheries Management" kondisi "poor" pada tiap atribut masih ada, akan tetapi hal tersebut juga diimbangi dengan adanya kondisi "fairly" pada atribut "Biological, physical and technical,

Market (supply-demand), characteristics of fisher".

Namun pada perkembangan selanjutnya terdapat model "Co-Management" yang lebih unggul dibanding dengan model "Community
Base Fisheries Management" keunggulan tersebut bisa dilihat pada atribut "Fisher/community institutional and organizational arrangement, external institutional and organizational arrangement serta exogeneous factor" dan secara umum pada model "Co-Management" hal ini bisa dilihat dari kondisi "fairly" yang mendominasi tiap atribut pada model Co-Management.

Pada model pengelolaan perikanan berbasis ekosistem walaupun sebagian besar atribut pada pengelolaan berbasis ekosistem menunjukkan kondisi "good" akan tetapi, masih terdapat kondisi yang masih menunjukkan "fairly" dimana hal tersebut berarti sama dengan model "Co-Management", atribut yang diprediksi akan tetap berada pada kondisi "fairly", yaitu atribut 

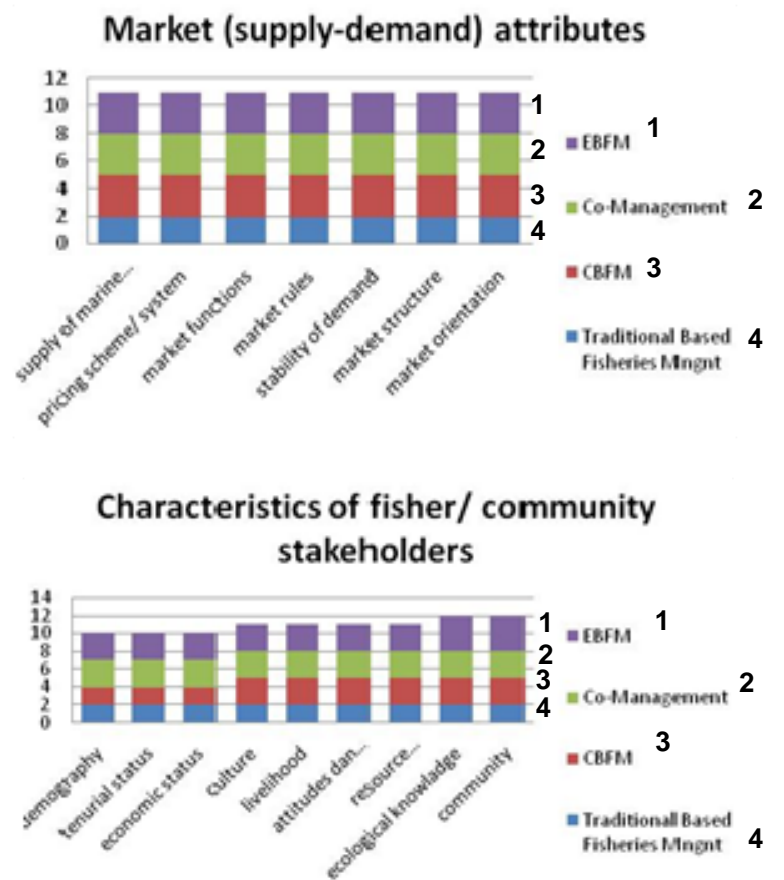

External institutional and organizational arrangements

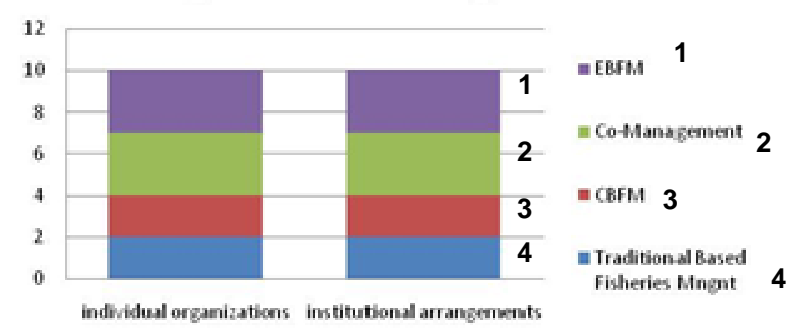

Biological, physical dan Technical Attributes

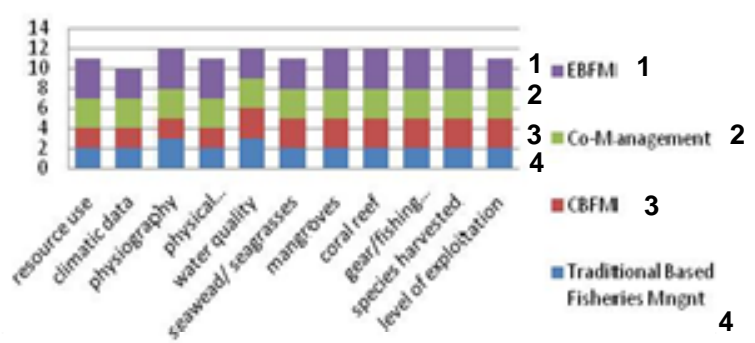

Fisher/community institutional dan organizational arrangements

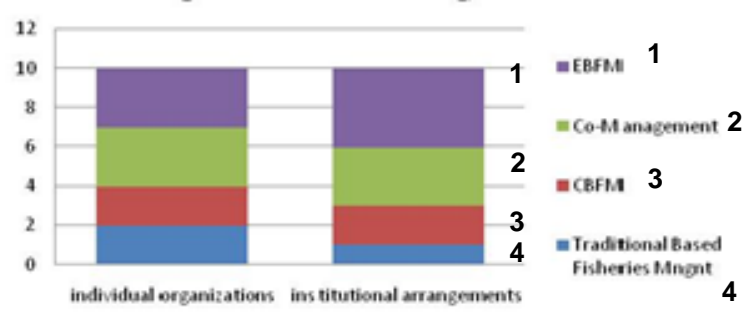

Exogenous factors

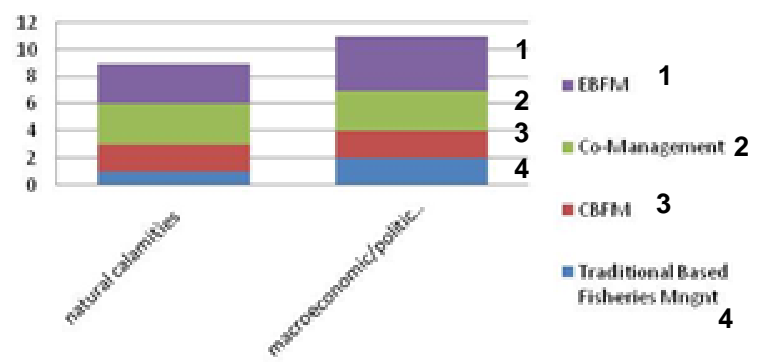

Gambar 4. Hasil Metode RAFMS untuk Biological, Physical dan Technical Attributes, Market Supply-Demand Atributes, Characteristics of Fisher / Community Stakeholders

"Market (supply-demand), external institution and organizational arrangement".

Metode penilaian model pengelolaan dengan RAFMS terdiri dari delapan atribut, di mana masing-masing atribut analisis terdiri dari beberapa indikator penilaian keberhasilan. Pada penelitian ini, penilaian pada metode ini dilakukan dengan memberikan skala ordinal yang terdiri dari empat tingkat yaitu bad, poor, fairly dan good.

Berdasarkan grafik yang menunjukkan hasil RAFMS pada ketiga panel ahli bahwa pada atribut Biological, Phusical, dan Technical atributes dapat diketahui bahwa model pengelolaan perikanan dengan EBFM lebih baik dibanding model pengelolaan traditional, CBFM maupun Co-Management, dimana ada tujuh jawaban "good" yang tidak didapati pada model pengelolaan tradisional, CBFM maupun CoManagement, dan empat jawaban "fairly" yang menunjukkan bahwa model pengelolaan EBFM adalah paling unggul hingga saat ini. Untuk indikator kualitas air berada pada kondisi yang sama untuk model keempat pengelolaan yang diamati dengan nilai yang sama yaitu "fairly".

Pada model pengelolaan traditional dan pengelolaan berbasis masyarakat (CBFM) menunjukkan hasil yang tidak baik dimana pada beberapa indikatornya terdapat empat jawaban "poor" dan tujuh jawaban "fairly". Pada model pengelolaan tradisional ini benarbenar masih ditemui cara yang sangat terkesan kuno, tidak efisien bahkan kurang memperhatikan alam, serta masih sangat minimnya 
penggunaan sumberdaya pada pengelolaan perikanan.

Pada atribut biological tersebut, jawaban panel ahli menunjukkan bahwa untuk Ekosistem Karimunjawa berada pada kondisi buruk pada pengelolaan secara tradisional. Dimana pada indikator-indikator yang menunjukkan habitat-habitat ekosistem dinilai "poor", sedangkan diprediksikan bahwa model pengelolaan EBFM adalah yang terbaik hingga saat ini. Pada model pengelolaan berbasis masyarakat (CBFM) dan Co-Management di tiap indikator pada atribut ini menunjukkan jawaban "fairly". Maka dapat kita ketahui bahwa hingga saat ini, EBFM adalah pendekatan yang paling baik.

Untuk technical attributes, pengelolaan dengan model tradisional menunjukkan hasil yang kurang baik dengan status "poor" di semua indikatornya. Pada model pengelolaan berbasis masyarakat (CBFM) dan Co-Management, kondisi "fairly" mendominasi pada semua indikator. Pada model ini, teknologi mesin dan alat tangkap lebih maju dibanding pada model pengelolaan tradisional. Selain itu, pengetahuan masyarakat mengenai spesies yang ditangkap sudah lebih baik dibandingkan pada model pengelolaan tredisional, serta pemerintah lebih banyak melakukan pemantauan dengan bermacam kebijakan mengenai perairan Indonesia dari waktu ke waktu. Untuk model pengelolaan berbasis ekosistem, diharapkan terjadi kondisi yang semakin baik pada semua indikator, kecuali pada indikator "level of explitation". Diharapkan kondisi minimal tetap "fairly" (tidak turun menjadi "poor" bahkan "bad") pada indikator ini, dikarenakan ada kekhawatiran akibat semakin majunya mesin dan alat tangkap menyebabkan bertambah rusaknya lingkungan apabila mesin atau alat yang digunakan tidak ramah lingkungan.

Hasil wawancara dengan ketiga panel ahli menunjukkan bahwa pada atribut market (supply-demand), model pengelolaan tradisional masih menunjukkan kinerja yang tidak baik untuk mengelola sumberdaya perikanan, dengan nilai "poor" yang mendominasi di semua indikatornya. Berdasarkan grafik market (supply-demand) attributes, dapat diketahui bahwa jawaban para panel ahli menunjukkan pengelolaan tradisional kurang tepat untuk mencapai indikator-indikator pasar (penawaran dan permintaan), kemudian untuk pengelolaan berbasis masyarakat/CBFM dan Co-Management menunjukkan status "fairly" yang artinya pengelolaan CBFM maupun Co-Management lebih baik daripada pengelolaan tradisional, karena menyangkut kemampuan sumber daya manusianya yang kurang kompeten dan masih sangat biasa. Untuk pengelolaan dengan EBFM dinilai bahwa tetap akan berada pada kondisi "fairly" di tiap indikator pasarnya.

Pada model EBFM, walaupun dinilai semua indikator akan menampilkan kinerja yang baik, tapi tetap perlu memberikan perhatian pada indikator-indikator Biological dan technical attributes yang diprediksi akan memburuk keadaannya. Hal ini disebabkan, sekarang sumberdaya perikanan hampir atau bahkan mengalami overfishing dan daya dukung lingkungannya pun sudah berkurang atau dengan kata lain terdegradasi. Maka dibutuhkan waktu yang cukup lama untuk mengembalikan kondisi lingkungan seperti semula, serta terwujudnya sumberdaya perikanan yang memiliki kemampuan lebih dari kapasitas, sehingga apabila sumberdaya perikanan ini digunakan, maka stok ikan akan mampu bertahan secara berkelanjutan (sustainable). Selain itu, aspek-aspek seperti aspek ekonomi atau sosial harus tetap diperhatikan dalam pengelolaannya agar seluruh tujuan yang pada masyarakat dapat dicapai.

Sedangkan pada atribut Characteristics of Fisher/Community Stakeholder terdapat beberapa indikator yang digunakan dalam menilai keberhasilan setiap pengelolaan yang digunakan, antara lain indikator demography, tenurial status, economic status, culture, livelihood, attitude and outlook of fisher, resource use, ecological knowledge dan community. Setiap indikator tersebut memiliki nilai yang berbeda pada tiap sistem pengelolaannya. Pada sistem pengelolaan tradisional, seluruh indikator tersebut menunjukkan nilai "Poor", artinya pada sistem pengelolaan tradisional, kondisinya masih jauh dari yang diharapkan. Sedangkan pada sistem pengelolaan CBFM, hanya tiga indikator saja yang masih menunjukkan kondisi "Poor", yaitu pada indikator demography, tenurial status dan economic status, hal ini menunjukkan bahwa pada 
sistem pengelolaan CBFM, belum memberikan pengaruh yang baik kepada ketiga indikator tersebut, sehingga kondisinya masih buruk, sedangkan untuk indikator lainnya sudah termasuk dalam keadaan "Fairly". Kondisi yang berbeda terdapat saat menggunakan sistem pengelolaan Co-Management, dimana kondisi seluruh indikator sudah menunjukkan hasil "fairly", artinya pada sistem pengelolaan ini, sudah ada keadaan yang lebih baik dibandingkan sistem pengelolaan sebelumnya, terutama dalam indikator demography, tenurial status dan economics status, yang pada sistem pengelolaan sebelumnya menunjukkan hasil "Poor" yang kini dengan sistem pengelolaan Co-Management, telah menunjukkan hasil "fairly", yang mengindikasikan telah terjadi perbaikan dalam hal demografi, tenurial dan tingkat ekonomi masyarakat sekitar daerah tersebut. Sedangkan pada sistem pengelolaan berbasis ekosistem atau EBFM, kondisinya telah mengalami perubahan ke arah yang lebih baik, hal ini ditunjukkan dengan perubahan hasil yang didapat dari pengelolaan sebelumnya apabila dibandingkan dengan pengelolaan EBFM, dimana pada indikator ecology knowledge dan community, ia menunjukkan hasil "Good", hal ini menunjukkan bahwa pengelolaan dengan sistem EBFM telah mampu menumbuhkan rasa peduli dan pengetahuan ekologi akan pengambilan sumber daya alam dengan dapat terus menjaga sumber daya alam yang terdapat di daerah tersebut.

Pada atribut Fisher/Community Institutional dan External Institutional and Organizational Arrangements, terdapat dua indikator penilaian yaitu individual organization dan institutional arrangements. Kedua indikator ini digunakan untuk menilai proses pembuatan kebijakan, legilasi pemerintah dan hukum yang terkait dengan pengelolaan perikanan, baik untuk masyarakat nelayan maupun pihak eksternal terkait.

Bagi masyarakat nelayan, indikator individual organizations dan institutional organizations, keduanya menunjukkan bahwa sistem pengelolaan yang akan menunjukkan hasil yang paling baik apabila menerapkan sistem pengelolaan berbasis ekosistem (EBFM) dengan hasil "Good" pada indikator institutional arrangement, dan hasil "Fairly" pada sistem pengelolaan CoManagement. Sedangkan untuk sistem pengelolaan yang lain seperti CBFM dan Tradisional, keduanya menunjukkan hasil "Poor", bahkan "Bad' untuk indikator institutional organizations pada sistem pengelolaan Tradisional. Hal yang sama juga terlihat pada atribut External Institutional and Organizational Arrangements, dimana hasil yang baik akan diperoleh apabila menerapkan sistem pengelolaan EBFM dan Co-Management dengan hasil "Fairly", jika dibandingkan dengan sistem pengelolaan lain seperti CBFM dan Traditional dengan hasil "Poor".

Sementara itu, pada atribut terakhir yakni Fisher/Community Institutional dan Organizational Arrangements, kondisinya tidak jauh berbeda dengan atribut sebelumnya, dimana hasil yang paling baik ditunjukkan apabila menerapkan sistem pengelolaan EBFM dengan hasil "Good" pada indikator macroeconomic dan "Fairly" pada indikator natural calamities.

(2) Hasil Analisis Raphfish. Dalam analisis Raphfish ini terdiri dari lima analisis multidisiplin, yaitu Ecological Analysis, Economic Analysis, Sociological Analysis, Technological Analyis dan Ethical Analysis, dimana masingmasing atribut analisis terdiri dari beberapa indikator penilaian keberhasilan.

Gambar 5 merupakan hasil evaluasi keseluruhan jumlah jawaban dari para ahli. Pada model pengelolaan tradisional, kondisi 'poor' dan 'fairly' masih banyak terjadi, yaitu pada analisis teknologi, ekonomi, dan ekologi. Hal ini dikarenakan pada pengelolaan tradisional tingkat pengetahuan dan teknologi masyarakatnya sendiri masih rendah, di sini campur tangan pemerintah dalam pengelolaan juga masih rendah, sehingga kondisi teknologi, ekonomi dan ekologi bisa dikatakan belum dapat dimanfaatkan secara optimal untuk sumberdaya perikanan. Namun kondisi untuk analisis sosial dan etikanya cukup bagus. Berdasarkan rata-rata keseluruhan jawaban yang didapat dari para ahli,di dalam aspek ini mengalami kondisi yang fairly dan poor. Hal ini dikarenakan kepercayaan dan adat masyarakat dan budaya yang berlaku di masyarakat setempat masih sangat kuat.

Sedangkan pada pengelolaan sumberdaya perikanan berbasis komunitas (CBFM), dalam 


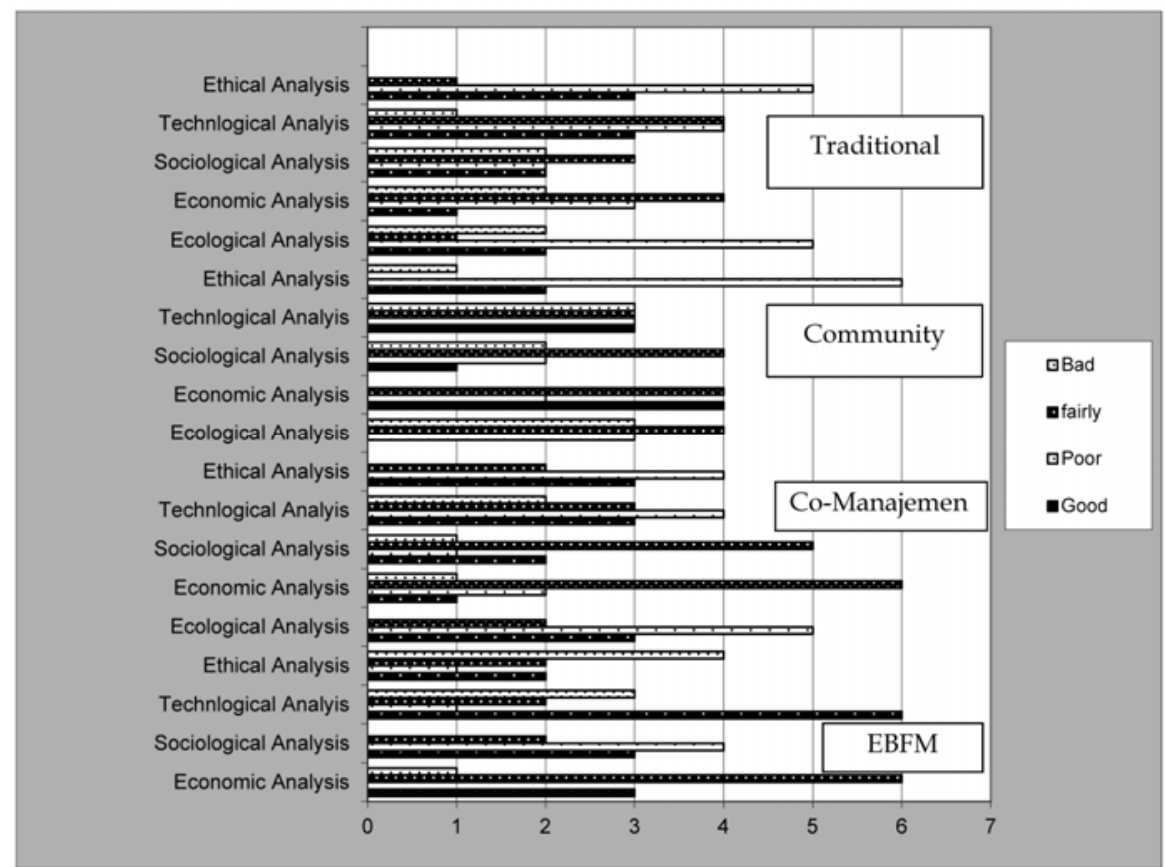

Sumber: data primer diolah, 2012

Gambar 5. Hasil Evaluasi Model Pengelolaan Perikanan dengan Metode RAPFISH

kondisi yang wajar (fairly) masih mendominasi tiap aspek. Sedangkan kondisi jelek (bad) tidak mendominasi dalam kondisi ini. Hal ini dikarenakan pada model pengelolaan ini, masyarakat sudah memiliki tingkat pengetahuan yang cukup untuk mengelola sumberdaya perikanan, walaupun di sini campur tangan pemerintah masih dibilang masih rendah. Oleh karena itu,agar terjadi keseimbangan pembagian tanggungjawab antarmasyarakat dan pemerintah. Dengan ini maka ada pengelolaan Co-Management. pada model ini masyarakat dan pemerintah sudah ikut berpartisipasi dalam pengelolaan walaupun belum sepenuhnya dan hasil yang didapatkan belum optimal. Hasil jawaban dari pada ahli menunjukkan bahwa masih terdapat kondisi 'bad' dan 'fairly'.

Pada model pengelolaan berbasis ekosistem, para ahli berpendapat dan memprediksi jika diterapkan di Indonesia ternyata cukup berpotensi. Kondisi 'good' dan 'fairly' telah mendominasi dalam analisis ini. Dengan adanya kondisi 'good' dan 'fairly' ini maka menunjukkan pengelolaan model EBFM akan dapat diterapkan di Indonesia dibanding dengan model analisis yang lainnya.

\section{Prospek Model Pengelolaan Perikanan Berbasis Ekosistem (EBFM)}

Di beberapa negara dunia sedang mencoba untuk mengembangkan kerangka implementasi untuk pengelolaan sumberdaya perikanan berbasis ekosistem/Ecosystem Based Fisheries Management (EBFM). Bentuk pengelolaan ini muncul sebagai akibat bahwa kebutuhan kebutuhan untuk memasukkan analisis ekosistem ke dalam pengelolaan sumberdaya perikanan sangat penting. Hal ini dikarenakan sumberdaya perikanan merupakan sumberdaya yang bersifat terbuka, sehingga siapa saja boleh berpartisipasi dalam mengambil manfaat dari sumberdaya ini. Selain itu, sumberdaya ini tersedia di wilayah pesisir dan laut (Bengen, 2001). Sebagai suatu ekosistem, wilayah pesisir dan laut tidak hanya menyediakan sumberdaya perikanan, tetapi terdapat pula sumberdaya alam hayati lainnya seperti mangrove, terumbu karang dan rumput laut; dan sumberdaya alam nir-hayati, di antaranya sumberdaya mineral, minyak bumi dan gas alam. Dengan demikian, pembahasan tentang pengelolaan sumberdaya perikanan tidak terlepas dari wilayah pesisir 
dan laut serta ekosistem terkait yang ada di dalamnya, sehingga analisis ekosistem menjadi elemen yang penting dalam pengelolaan sumberdaya perikanan (Trites et al. 1999, Bundy dan Pauly 2001, Gasalla dan Rossi-Wongtschowski 2004, Coll et al. 2007).

Secara khusus, EBFM bertujuan untuk menilai dan mengelola dampak atau keluaran ekologi, sosial dan ekonomi yang terkait dengan kegiatan perikanan dalam satu ekosistem yang spesifik (Fletcher, 2005). Seperti uraian pada bab sebelumnya, telah diketahui bahwa kebutuhan untuk memasukkan analisis ekosistem ke dalam pengelolaan sumberdaya perikanan diakui telah diterima secara luas (Arkema et. al. 2006). Namun secara formal, metodologi untuk aplikasi penerapan EBFM memang belum dihasilkan (Marasco, 2007).

Penerapan EBFM di Filipina yang juga merupakan negara berkembang seperti Indonesia menunjukkan bahwa dalam implementasi EBFM, cara yang terbaik adalah dengan memasukkannya dan melengkapinya dengan struktur pemerintahan atau model pengelolaan yang sudah ada. Hal ini dikarenakan, EBFM bukanlah sebuah model substitusi untuk melanjutkan bentuk pengelolaan apa yang sudah dilakukan, tapi suatu pendekatan yang dibutuhkan sebagai cara selanjutnya untuk memperbaiki ekosistem.

Indonesia sebagai negara kepulauan dan secara geografis dikelilingi oleh lautan menyebabkan sebagian besar penduduk Indonesia bermata pencaharian sebagai nelayan. Oleh karena itu, subsektor perikanan merupakan subsektor yang penting bagi Indonesia untuk dikelola dan dijaga agar tetap lestari (berkelanjutan).

Berdasarkan pengalaman negara Filipina, menunjukkan bahwa penerapan EBFM mungkin dilakukan di Indonesia. Namun, keberhasilan bentuk model ini tidak bisa diharapkan dalam jangka pendek. Dibutuhkan biaya, waktu dan sumberdaya manusia untuk mengimplementasikan model ini. Selain itu, penerapan model ini harus didukung oleh politik, hukum, kebijakan, budaya dan kesediaan masyarakat untuk mematuhi aturan penerapan pengelolaan sumberdaya perikanan berbasis ekosistem.
Berikut disediakan tabel identifikasi prospek keberhasilan untuk penerapan EBFM di Indonesia dengan menggunakan kunci kondisi yang dikembangkan oleh Ostrom (1990, 1992); Pinkerton (1989); dan Susilowati (2006) dan 12 indikator keberhasilan EBFM dari Grieve, Chris and Katherine Short (2007).

Secara umum dapat disimpulkan bahwa penerapan co-management dan CBFM di beberapa daerah di Indonesia belum bisa dirasakan hasilnya secara optimal. Padahal, kondisi sumberdaya perikanan, baik kuantitas maupun kualitas, semakin menurun.

Munculnya paradigma baru dalam pengelolaan perikanan dan melihat peluang keberhasilan pada implementasi model tersebut di beberapa negara lain, maka Indonesia berpotensi dalam mengaplikasikan model pengelolaan sumberdaya perikanan berbasis ekosistem.

Secara teoritis, identifikasi prospek model pengelolaan sumberdaya perikanan yang telah dilakukan (lihat Tabel 1 dalam lampiran) menunjukkan peluang memungkinkannya model tersebut diterapkan. Namun, apabila secara lapangan, berdasarkan wawancara mendalam pada daerah studi empiris, model ini akan sulit untuk diterapkan. Hal ini dikarenakan wilayah yang terlalu luas apabila dikelola berdasarkan batasan ekosistem, sedangkan tingkat komunikasi dan kepedulian antarstakeholders sumberdaya perikanan masih sangat rendah. Daya dukung fasilitas dan pendanaan adalah hambatan utama juga dalam menerapkan model ini. Ada alternatif lain apabila ingin menerapkan model ini, yaitu dengan dibentuknya sebuah tim untuk penilaian ekosistem dalam tataran pemerintah dengan kebijakan masing-masing pemerintah daerah. Kemudian dalam tataran masyarakat dibentuk sebuah komunitas pada masing-masing daerah, lalu dipilih ketua untuk memfasilitasi seluruh daerah tersebut. Pada prakteknya, tim penilai ekosistem ini akan mengkomunikasikan hasilnya kepada komunitas daerahnya.

Kemudian, masing-masing komunitas dengan kerjasama satu dengan lainnya agar tidak terjadi konflik daerah yang akan mensosialisasikan dan menerapkan hasil peni- 
laian tim ekosistem kepada masyarakat nelayan. Adapun komunitas ini terdiri dari tokoh masyarakat, nelayan dan LSM. Sedangkan tim penilaian ekosistem terdiri dari pemerintah, baik pusat maupun daerah, akademisi, LSM, serta lembaga penelitian lain.

\section{Penjajagan Strategi Pengelolaan Sumber- daya Perikanan Berbasis Ekosistem}

Strategi pengelolaan perikanan berbasis ekosistem dirumuskan berdasarkan hasil diskusi panel dan wawancara mendalam dengan keyperson (pendekatan kualitatif) dan hasil analisis AHP (Analysis Hierarchy Process) sebagai bukti kuantitatif telah memberikan beberapa butir prioritas, meskipun masih kasar dan perlu ujicoba penerapan modelnya. Berdasarkan hasil diskusi, ada lima aspek yang diidentifikasikan, yaitu aspek ekologi, aspek sosial, aspek ekonomi, aspek kelembagaan dan aspek lingkungan maka hasil analisis secara keseluruhan dapat dilihat pada Gambar 6. Ada tiga prioritas utama dalam pengelolaan perikanan adalah membuat basis data ikan tangkap dengan nilai bobot 0,218 , disusul peningkatan pengetahuan pengelolaan perikanan dengan nilai bobot 0,158 ; dan mengembangkan kebijakan rencana pengelolaan dengan nilai bobot 0,109. Nilai inconsistensy ratio secara keseluruhan sebesar 0,06<0,1 (batas maksimum) yang berarti hasil analisis dapat diterima.

Hasil analisis para responden menunjukkan bahwa aspek ekologi (nilai bobot 0,372) merupakan aspek yang paling penting untuk diperhatikan dalam pengelolaan perikanan

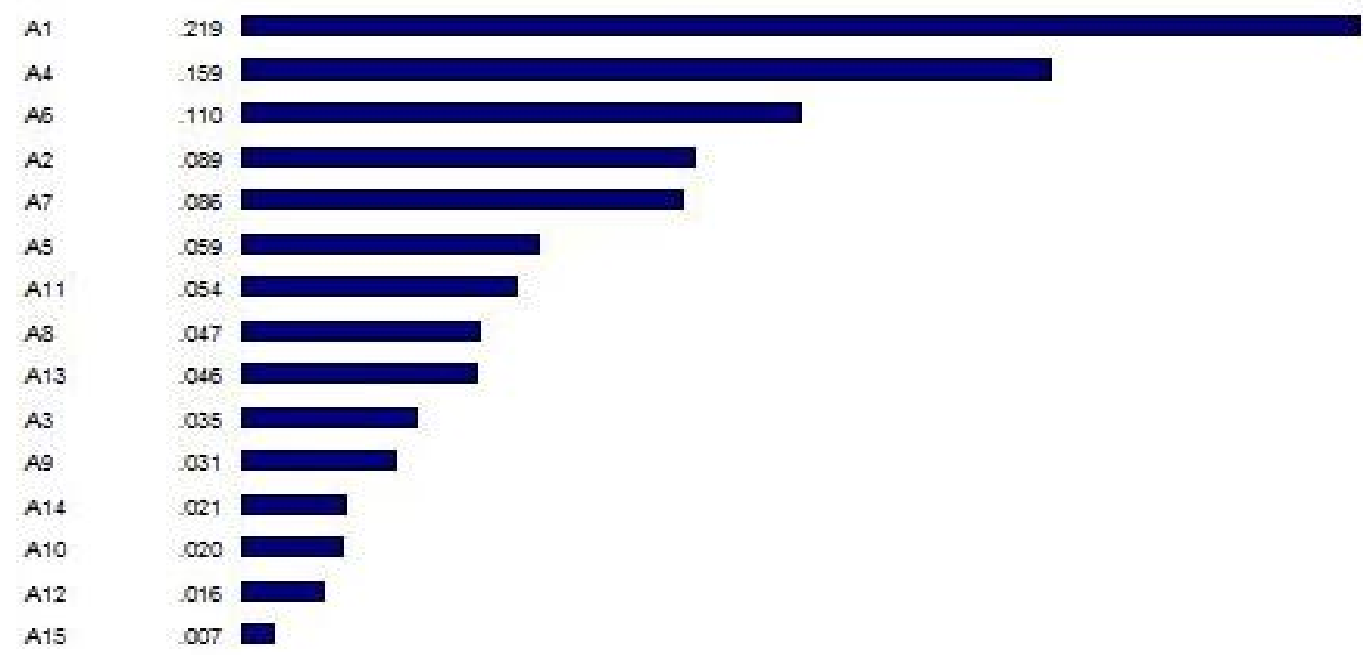

Sumber: Output AHP, 2011

\title{
Gambar 6. Prioritas Alternatif Pengelolaan Perikanan Berbasis Ekosistem di Karimunjawa
}

\begin{abstract}
Keterangan:
A1 adalah membuat basis data yang menguraikan keterangan jenis-jenis ikan yang ditangkap. A2 adalah Membuat basis data yang menguraikan keterangan jenis-jenis ikan yang dilindungi. A3 adalah Memulihkan dan menjaga kondisi tempat hidup ikan (habitat). A4 adalah meningkatkan dan memberikan pengetahuan tentang pengelolaan perikanan kepada masyarakat nelayan. A5 adalah membuat kebijakan pengelolaan perikanan yang disesuaikan dengan nilai budaya masyarakat setempat. A6 adalah mengembangkan kebijakan terkait rencana pengelolaan secara lebih jelas untuk sumberdaya perikanan. A7 adalah mengembangkan dan meningkatkan penelitian dalam bidang perikanan. A8 adalah meningkatkan pengawasan terhadap pengelolaan perikanan. A9 adalah meningkatkan dan menjaga komunikasi dengan stakeholders. A10 adalah meningkatkan dan menjaga komunikasi dengan kementerian/ dinas pemerintah terkait. A11 adalah Identifikasi dampak kegiatan perikanan yang terjadi pada direct stakeholders dari sisi ekonomi. A12 adalah identifikasi dampak kegiatan perikanan yang terjadi pada indirect stakeholders dari sisi ekonomi. A13 adalah dapat memprediksi dan membuat perencaanan solusi untuk mengatasi dampak perubahan iklim bagi kegiatan perikanan. A14 adalah dapat memprediksi dan membuat perencaanan solusi untuk mengatasi dampak gejala alam lainnya (abrasi, sedimentasi, akresi) bagi kegiatan perikanan. A15 adalah mengurangi faktor manusia (man made) yang dapat menyebabkan kerugian bagi kegiatan perikanan dan ekosistem di dalamnya.
\end{abstract}


berbasis ekosistem. Aspek berikutnya yang penting adalah aspek sosial (nilai bobot 0,270), aspek kelembagaan (nilai bobot 0,187), aspek ekonomi (nilai bobot 0,092) dan aspek lingkungan eksternal (nilai bobot 0,079). Nilai inconsistency ratio 0,05 < 0,1 (batas maksimum) yang berarti hasil analisis tersebut dapat diterima. Setiap aspek yang dipertimbangkan dalam pengelolaan perikanan berbasis ekosistem dapat dilihat pada Gambar 7.

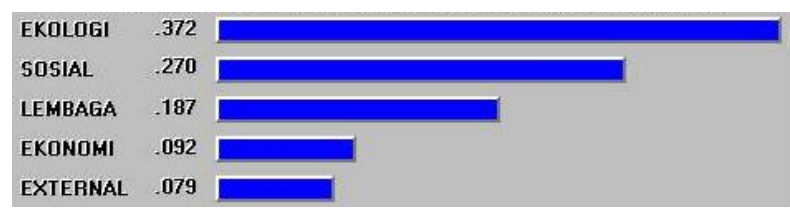

Gambar 7. Prioritas Aspek Pengelolaan Perikanan Berbasis Ekosistem di Karimunjawa

\section{Model Kelembagaan Pengelolaan Perikanan Berbasis Ekosistem}

Penyesuaian secara kelembagaan adalah salah satu cara agar dapat mengimplementasikan EBFM dan mengelola perikanan dengan memperhitungkan berbagai aspek terkait dalam ekosistem, sehingga dapat menyeimbangkan seluruh tujuan yang ada pada masyarakat.

Sistem pemerintahan Indonesia yang desentralisasi menyebabkan setiap daerah mempunyai wewenang dalam mengelola sumberdaya perikanan di daerahnya masingmasing. Padahal, sebagaimana yang telah dijelaskan sebelumnya, sumberdaya perikanan tidak dapat dipisahkan secara batas administratif. Diperlukan pengelolaan secara komprehensif agar sumberdaya perikanan lestari (berkelanjutan). Embrio kelembagaan pelaksanaan EBFM yang diusulkan pada studi ini adalah terinspirasi dari Maryland Sea Grant Ecosystem-Based Fisheries Management Planning oleh Houde (2009). Untuk itu maka perlu dilakukan pembentukan wilayah pengelolaan berbasis ekosistem untuk daerah penelitian. Kemudian dari masing-masing wilayah perlu dibentuk beberapa Tim Penilaian Ekosistem yang akan menilai dan memantau (monitoring) kondisi yang terjadi terkait dengan sumberdaya perikanan. Adapun tim tersebut adalah Tim Keberlanjutan Habitat, Tim Stock Assessment, Tim Sosial-Ekonomi dan Tim Ketahanan
Pangan. Untuk mengkoordinasikan tugas dan memantau kinerja dari tiap tim, maka dibutuhkan daerah protokol yang bertanggung jawab. Daerah yang menjadi protokol ini ditunjuk berdasarkan kesepakatan bersama.

Untuk mendukung kinerja dari tiap tim maka dibutuhkan kerjasama dari berbagai lembaga yang sudah ada/dibentuk seperti Dewan Maritim Indonesia, LIPI, Panitia Koordinasi Wilayah Nasional dan Dasar Laut, Bappenas, Kementerian/Dinas lain terkait dengan pengelolaan sumberdaya perikanan, akademisi, LSM atau lembaga penelitian lain, agar kebijakan yang diambil nantinya berdasarkan analisis ilmiah dan teknis yang akurat, karena dilakukan oleh pihak-pihak yang ahli dan terkait di dalamnya. Sedangkan Dinas Kelautan dan Perikanan Provinsi dan Kementerian Kelautan dan Perikanan, tetap berperan sebagaimana yang telah ditetapkan sebelumnya. Kemudian tim penilai ekosistem ini akan mengkomunikasikan hasilnya kepada komunitas daerahnya. Lalu komunitas tersebut yang akan mensosialisasikan dan menerapkan hasil penilaian tim ekosistem kepada masyarakat nelayan.

Tim Penilaian Ekosistem ini perlu dibentuk mengingat kinerja evaluasi dan monitoring/ pengawasan masih rendah. Tim ini adalah lembaga independen yang terdiri dari perwakilan masing-masing stakeholders. Tim ini merupakan media antara pusat dan daerah, daerah dan masyarakat, sehingga akan berdomisili di daerah yang menjadi protokol pengelolaan wilayah berbasis ekosistem.

Usulan rencana pengelolaan sumberdaya perikanan disusun berdasarkan kebijakan yang telah dibuat oleh pemerintah baik pusat maupun daerah, yaitu mengacu pada kebijakan UU RI No. 32 Tahun 2004 tentang Otonomi Daerah, UU RI No. 27 Tahun 2007 tentang Pengelolaan Wilayah Pesisir dan Pulau-Pulau Kecil dan Perda Provinsi Jawa Tengah No.9 Tahun 2009 tentang Pengelolaan Wilayah Pesisir dan PulauPulau Kecil di Provinsi Jawa Tengah. Hal ini juga sudah diverifikasi dengan wawancara mendalam dengan salah satu Kepala Bidang Dinas Provinsi Jawa Tengah.

Upaya untuk mewujudkan pengelolaan sumberdaya perikanan yang berkelanjutan 


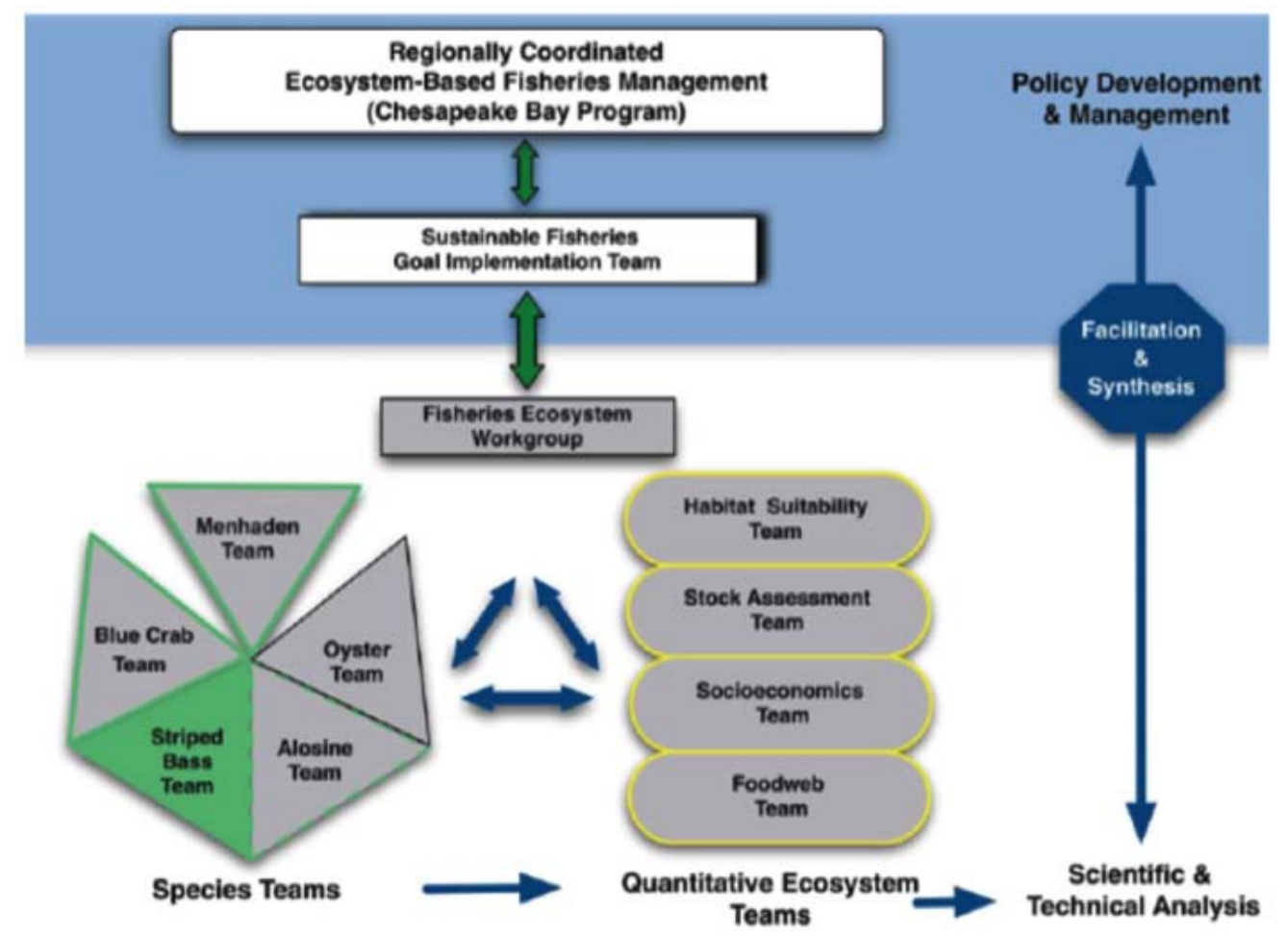

Sumber: Houde,2009

Gambar 8. Maryland Sea Grant Ecosystem-Based Fisheries Management Planning

harus dilakukan pembagian dan tanggung jawab antarpemerintah dan masyarakat. Berikut adalah bagan usulan rencana kelembagaan pengelolaan perikanan berbasis ekosistem yang disesuaikan dengan kebijakan dan kelembagaan yang ada.

Berdasarkan Gambar 8, maka diusulkan perlunya pembentukan wilayah pengelolaan berbasis ekosistem. Kemudian dari masingmasing wilayah ini dibentuk beberapa Tim Penilaian Ekosistem yang akan menilai dan memantau (monitoring) kondisi yang terjadi terkait dengan sumberdaya perikanan. Adapun tim tersebut adalah Tim Keberlanjutan Habitat, Tim Stock Assessment, Tim Sosial-Ekonomi dan Tim Ketahanan Pangan. Untuk mengkoordinasikan tugas dan memantau kinerja dari tiap tim, maka dibutuhkan daerah protokol yang bertanggung jawab. Daerah yang menjadi protokol ini ditunjuk berdasarkan kesepakatan bersama.

Untuk mendukung kinerja dari tiap tim maka dibutuhkan kerjasama dari berbagai lembaga yang sudah ada/dibentuk seperti Dewan Maritim Indonesia, LIPI, Panitia Koordinasi Wilayah Nasonal \& Dasar Laut, Bappenas, Kementerian/Dinas lain terkait dengan penge- lolaan sumberdaya perikanan, akademisi, LSM atau lembaga penelitian lain, agar kebijakan yang diambil nantinya berdasarkan analisis ilmiah dan teknis yang akurat, karena dilakukan oleh pihak-pihak yang ahli dan terkait di dalamnya. Sedangkan Dinas Kelautan dan Perikanan Provinsi dan Kemeterian Kelautan dan Perikanan, tetap berperan sebagaimana yang telah ditetapkan sebelumnya. Kemudian tim penilai ekosistem ini akan mengkomunikasikan hasilnya kepada komunitas daerahnya. Lalu komunitas tersebut yang akan mensosialisasikan dan menerapkan hasil penilaian tim ekosistem kepada masyarakat nelayan.

Tim Penilaian Ekosistem ini perlu dibentuk mengingat kinerja evaluasi dan monitoring/ pengawasan masih rendah. Tim ini adalah lembaga independen yang terdiri dari perwakilan masing-masing stakeholders. Tim ini merupakan media antara pusat dan daerah, daerah dan masyarakat, sehingga akan berdomisili di daerah yang menjadi protokol pengelolaan wilayah berbasis ekosistem.

Usulan rencana pengelolaan sumberdaya perikanan disusun berdasarkan kebijakan yang telah dibuat oleh pemerintah baik pusat mau- 


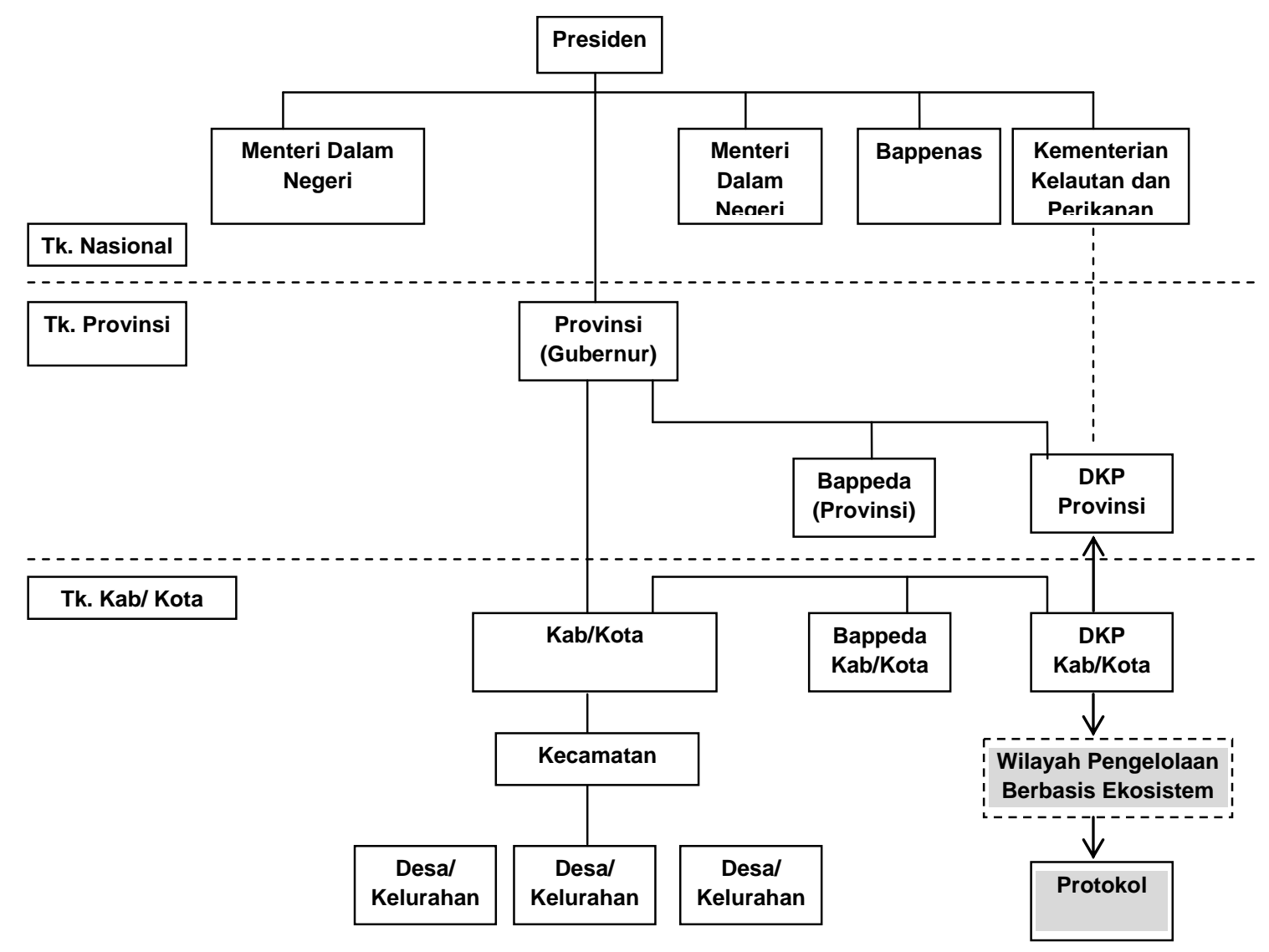

Sumber: Houde, 2009 dengan modifkasi oleh Susilowati (2012)

Gambar 9. Usulan Kelembagaan Rencana Pengelolaan Sumberdaya Perikanan Berbasis Ekosistem

pun daerah, yaitu mengacu pada kebijakan UU RI No. 32 Tahun 2004 tentang Otonomi Daerah, UU RI No. 27 Tahun 2007 tentang Pengelolaan Wilayah Pesisir dan Pulau-Pulau Kecil dan Perda Provinsi Jawa Tengah No. 9 Tahun 2009 tentang Pengelolaan Wilayah Pesisir dan PulauPulau Kecil di Provinsi Jawa Tengah. Hal ini juga sudah diverifikasi dengan wawancara mendalam dengan salah satu kepala bidang Dinas Provinsi Jawa Tengah .

Upaya untuk mewujudkan pengelolaan sumberdaya perikanan yang berkelanjutan harus dilakukan pembagian dan tanggung jawab antarpemerintah dan masyarakat. Gambar 9 yang menyajikan bagan usulan rencana kelembagaan pengelolaan perikanan berbasis ekosistem yang disesuaikan dengan kebijakan dan kelembagaan yang sudah ada.

\section{SIMPULAN}

(1) Model pengelolaan secara konvensional masih belum berhasil dalam mengelola sumberdaya. (2) Pengelolaan sumberdaya perikanan berbasis ekosistem sebagai paradigma baru diduga merupakan solusi bagi pengelolaan sumberdaya perikanan. Walaupun mungkin akan sulit dan dibutuhkan waktu yang lama untuk melihat keberhasilan model ini apabila diterapkan di Indonesia, bukan berari suatu usaha yang mustahil. Untuk menerapkan model ini bisa disesuaikan dengan kondisi dan seluruh karakteristik terkait dengan sumberdaya perikanan. (3) Untuk menyusun strategi pengelolaan sumberdaya perikanan berbasis ekosistem dilakukan dengan mempertimbangkan beberapa aspek yaitu aspek ekologi, aspek ekonomi, aspek sosial, aspek kelembagaan, dan aspek lingkungan. (4) strategi pengelolaan sumberdaya perikanan 
dilakukan dengan prioritas: (a) melakukan pemulihan dan menjaga kondisi tempat hidup (habitat) ikan; (b) membuat kebijakan pengelolaan perikanan yang disesuaikan dengan nilai budaya masyarakat; dan (c) membuat basis data tentang keterangan jenis-jenis ikan yang ditangkap. (5) Secara kelembagaan, pengelolaan perikanan berbasis ekosistem dapat diterapkan di Provinsi Jawa Tengah khususnya. Usulan rencana pengelolaan sumberdaya perikanan dalam bab pembahasan dapat dimplementasikan dengan mengacu pada kebijakan UU RI No. 32 Tahun 2004 tentang Otonomi Daerah, UU RI No. 27 Tahun 2007 tentang Pengelolaan Wilayah Pesisir dan Pulau-Pulau Kecil dan Perda Provinsi Jawa Tengah No.9 Tahun 2009 tentang Pengelolaan Wilayah Pesisir dan PulauPulau Kecil di Provinsi Jawa Tengah. (6) Pengelolaan sumberdaya perikanan berbasis ekosistem (EBFM) memberikan indikasi yang prospektif. Untuk itu disarankan perlu diujicoba implementasinya. Bila model EBFM yang diusulkan ini telah lolos uji maka kerangka implementasi EBFM. Sehingga diharapkan dapat diadopsi oleh daerah lain di Indonesia untuk mengelola sumber daya perikanannya.

\section{Ucapan Terima Kasih}

Ucapan terima kasih disampaikan kepada Mayanggita Kirana, S.E., M.Sc., sebagai anggota tim pengajar Mata Kuliah Sumberdaya Alam dan Lingkungan (ESDAL) di Fakultas Ekonomi dan Bisnis UNDIP atas bantuan menyelaraskan (meng-edit) tulisan ini. Apresiasi yang tinggi disampaikan kepada kelompok kerja mahasiswa ESDAL yang telah membantu mengumpulkan data untuk penelitian ini dengan penuh dedikasi.

\section{DAFTAR PUSTAKA}

Arkema, pK. K., Abramson, S. C. and Dewsbury, B.M. 2006. Marine Ecosystem-Based Management: From Characterization to Implementation. Frontiers in Ecology and the Environment, 4(10), 525-532. www. mendeley.com/.../marine-ecosystembasedmanagement-from-characterization-to-imple- mentation/- Amerika Serikat. Diakses tanggal 18 Oktober 2009.

Bengen, Dietrect G. 2001. Ekosistem dan Sumberdaya Alam Pesisir dan Laut: Sinopsis. Bogor: Pusat Kajian Sumberdaya Pesisir dan Lautan, Institut Pertanian Bogor.

Bundy, A. 2001. Fishing on Ecosystems: The Interplay of Fishing and Predation in Newfoundland-Labrador. Canadian Journal of Fisheries and Aquatic Science, 58, 1153-1167.

Coll, M., Santojanni, A., Palomera, I., Tudela, S. and Arneri, E. 2007. An Ecological Model of the Northern and Central Adriatic Sea: Analysis of Ecosystem Structure and Fishing Impacts. Journal of Marine Systems, 67, 119-154

DKP. 2005. Potensi Sumber Daya Pesisir dan Laut. Semarang: Dinas Kelautan dan Perikanan Provinsi Jawa Tengah.

DKP. 2005. Rencana Strategis Pembangunan Kelautan dan Perikanan Tahun 2005-2009. Jakarta: Departemen Kelautan dan Perikanan.

DKP. 2008. Konservasi Sumberdaya Ikan di Indonesia. Jakarta: Departemen Kelautan dan Perikanan.

DKP. 2009a. Kajian Komoditas Unggulan. Jakarta: Departemen Kelautan dan Perikanan.

DKP. 2009a. Pengelolaan, Rehabilitasi, dan Sistem Pengawasan Habitat Vital. Semarang: Dinas Kelautan dan Perikanan Provinsi Jawa Tengah.

DKP. 2009b. Pengelolaan Sumberdaya Perikanan. Jakarta: Departemen Kelautan dan Perikanan.

DKP. 2009b. Rencana Strategis Dinas Kelautan dan Perikanan Provinsi Jawa Tengah. Semarang: Dinas Kelautan dan Perikanan Provinsi Jawa Tengah.

DKP. 2009c. Indonesian Fishing Port 2009. Jakarta: Departemen Kelautan dan Perikanan. 
FAO Fisheries Department. 1995. The Code of Conduct for Responsible Fisheries. FAO Rome 41p.

FAO Fisheries Department. 2004. The State of World Fisheries and Aquaculture. FAO Rome: $153 p$

Fauzi dan Anna. 2005. Permodelan Sumberdaya Perikanan dan Kelautan. Jakarta: PT. Gramedia Pustaka.

Fauzi, A., and E. Buchary. 2002. A Socioeconomic Perspective of Environmental Degradation at Kepulauan Seribu National Park, Indonesia. Journal of Coastal Management, 30(2): pp 167-181.

Fauzi, A., dan S. Anna. 2002. Evaluasi Keberlanjutan Pembangunan Perikanan: Aplikasi Pendekatan RAFISH (Studi Kasus Perairan Pesisir DKI Jakarta). Jurnal Pesisir dan Lautan Vol 4 (3) 43 - 55.

Fauzi, Akhmad. 2006. Ekonomi Sumbe Daya Alam dan Lingkungan. Jakarta: Gramedia Pustaka.

Fletcher, W. J. 2005. The Application of Qualitative Risk Assessment Methodology to Prioritise Issue for Fisheries Management. Journal of Marine Science Vol 62: 1576-1587.

Fletcher, W.J. 2008. A Guide to Implementing an Ecosystem Approach to Fisheries Management (EAFM) for the Tuna Fisheries of the Western and Central Pacific Region. Forum Fisheries Agency, Honiara, Solomon Islands. Version 5 March 2008: 70.

Gasalla, M. A. and Rossi-Wongtschowski, C. L. D. B. 2004. Contribution of Ecosystem Analysis to Investigate the Effects of changes in Fishing Strategies in the South Brazil Bight Coastal Ecosystem. Ecological Modelling, 172, pp.283-306.

Grieve, Chris and Katherine Short. 2007. Implementation of Ecosystem Based Management in Marine Capture Fisheries (Case Studies From WWF's Marine Ecoregions). WWF EBM Toolkit. WWF International.
Marasco, R. J., Goodman, D., Grimes, C. B., Lawson, P. W., Punt, A. E. and Quinn II, T. J. 2007. Ecosystem-based Fisheries Management: Some Practical Suggestions. Canadian Journal of Fisheries and Aquatic Science, 64, 928-939.

Marasco, R. J., Goodman, D., Grimes, C. B., Lawson, P. W., Punt, A. E. and Quinn II, T. J. 2007. Ecosystem-based Fisheries Management: Some Practical Suggestions. Canadian Journal of Fisheries and Aquatic Science, 64, 928-939.

Ostrom, E. 1992. Ostrom, E. Crafting Insitutions for Self-governing Irrigation Systems. San Francisco, USA: Institute for Contemporary Studies Press.

Ostrom, E. (1990). Governing the Commons: the Evolution of Institutions for Collective Action. Cambridge, England: Cambridge University Press.

Pikitch, E. K., (dkk). 2004. Ecosystem-based Fisheries Management. Science, 305, 346347.

Pinkerton, E. Editor. 1989. Cooperative Management of Local Fisheries. Vancouver, Canada: University of British Columbia Press.

Pitcher, T.J. and Preikshot, D.B. 2001. Rapfish: A Rapid Appraisal Technique to Evaluate the Sustainability Status of Fisheries. Fisheries Research 49(3): 255-270

Pomeroy, Robert S., William Meryl J. 1994. Fisheries Co-Management and Small-Scale Fisheries: A Policy Brief. Manila: ICLARM.

Pomeroy, Robert, Len Garces, Micahel Pido, Geronimo Silvestre. 2009. Ecosystembased Fisheries Management in SmallScale Tropical Marine Fisheries: Emerging Models of Governance Arrangements in the Philippines. Journal of Elsevier: Marine Policy Vol 34: 298-308.

Pope, J. G., MacDonald, D. S., Daan, N., Reynolds, J. D. and Jennings, S. (2000) Gauging the Impact of Fishing Mortality on non-Target Species. ICES Journal of Marine Science, 57, 689-696. 
Susilowati, Indah and Sucihatiningsih DW Prajanti. 2012. Strategy for Enhancing Agriculture Performance in Central Java Province, Indonesia: An Application Of Mixed Methods. The 2012 Las Vegas International Business \& Economics Conference. Caesars Palace, Las Vegas, Nevada, USA. October 15-17, 2012

Susilowati, Indah. 2006. Keselarasan dalam Pemanfaatan dan Pengelolaan Sumberdaya Perikanan bagi Manusia dan Lingkungan. Pidato Pengukuhan Guru Besar Fakultas Ekonomi Universitas Diponegoro, Semarang.

Susilowati, Indah. 1999. "An Analysis of CoManagement Fisheries in West Sumatra Province, Indonesia: A Case Study of Ikan Larangan". Research Report. Manila, Philipines: International Center for Living Aquatic Resource Management (ICLARM).

Thohir, Mudjahirin (dkk). 2009. Kaji Tindak (Action Research) Moel Pemberdayaan
Masyarakat Pesisir yang Mandiri dalam Mendukung Ketahanan dan Keamanan Pangan di Pesisir Utara dan Pesisir Selatan Jawa Tengah (Studi Empiris pada Usaha Mikro Kecil Pengolah Ikan di Kab. Remabng dan Cilacap). Laporan Penelitian. Semarang: Lembaga Penelitian Universitas Diponegoro. Universitas Diponegoro.

Trites, A. W., Livingston, P. A., Vasconcellos, M. C., Mackinson, S., Springer, A. M. and Pauly, D. 1999. Ecosystem Considerations and the Limitations of Ecosystem Models in Fisheries Management: Insights from the Bering Sea. Alaska Sea Grant College Program, AK-SG-99-01, 609-619.

USA National Marine Fisheries Service.1999. Ecosystem Based Fishery Management: A Report to the Congress by the Ecosystem Principles Advisory Panel. http://www. nmfs.gov/sfa/reports.html. Diakses tanggal 18 Oktober 2009. 


\section{LAMPIRAN}

Tabel 1. Identifikasi Prospek Pengelolaan Perikanan Berbasis Ekosistem (EBFM) di Indonesia

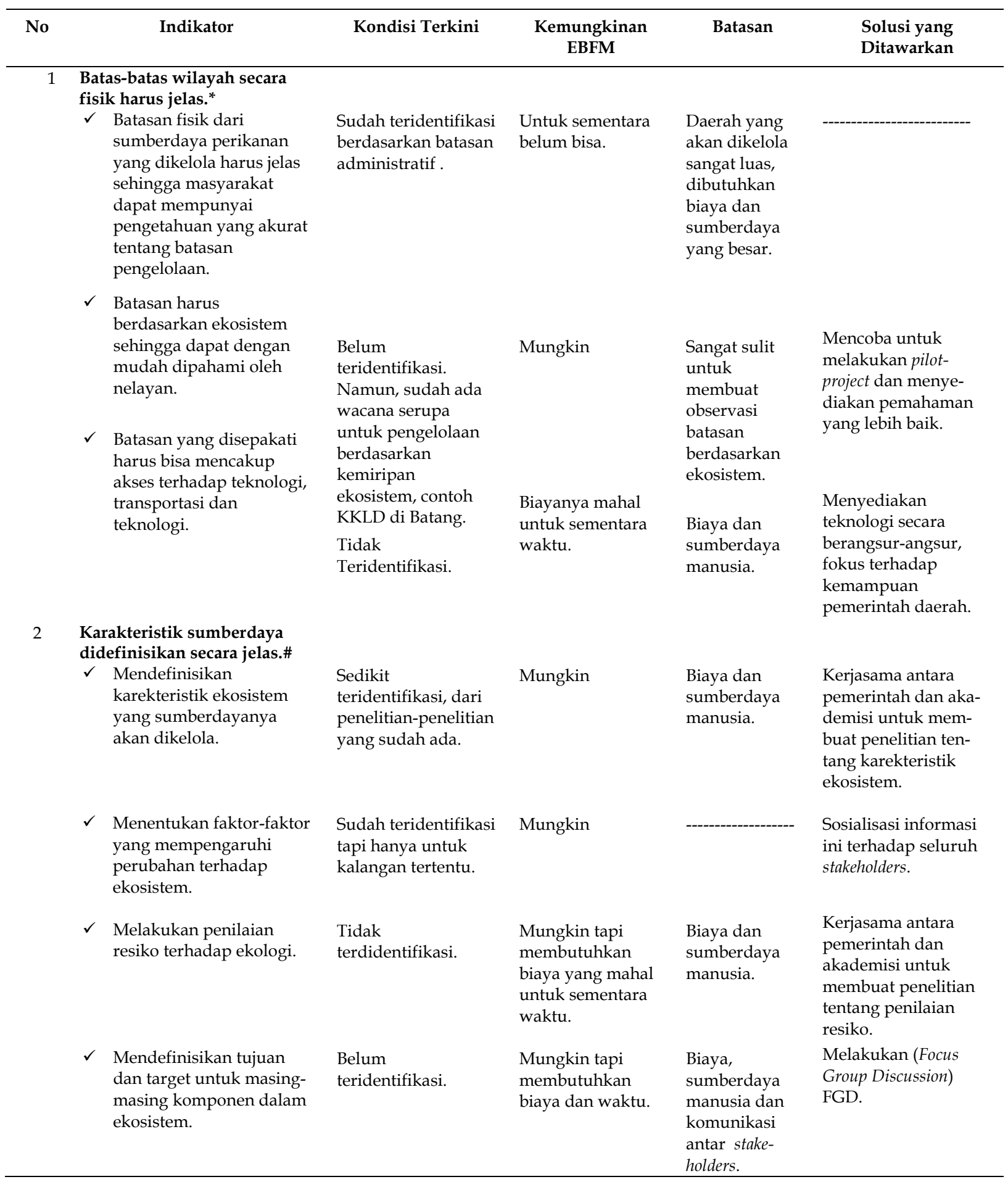




\begin{tabular}{|c|c|c|c|c|c|}
\hline 3 & $\begin{array}{l}\text { Keanggotaan didefinisikan } \\
\text { secara jelas.* } \\
\checkmark \quad \text { Masyarakat dengan hak } \\
\text { untuk mengambil/ } \\
\text { memanfaatkan } \\
\text { sumberdaya perikanan } \\
\text { dalam daerah penangkap- } \\
\text { an (fishing bounded) dan } \\
\text { berpartisipasi dalam } \\
\text { daerah pengelolaan harus } \\
\text { didefinisikan secara jelas. } \\
\checkmark \quad \text { Jumlah masyarakat } \\
\text { seharusnya tidak terlalu } \\
\text { besar agar komunikasi } \\
\text { dan pembuatan } \\
\text { keputusan lebih efektif. }\end{array}$ & Tidak teridentifikasi. & $\begin{array}{l}\text { Mungkin untuk } \\
\text { diimplementasika } \\
\text { n dengan } \\
\text { komitmen yang } \\
\text { kuat. }\end{array}$ & $\begin{array}{l}\text { Kekurangan } \\
\text { sumberdaya } \\
\text { manusia dan } \\
\text { fasilitas untuk } \\
\text { mengkoordina } \\
\text { si dan } \\
\text { melakukan } \\
\text { pengawasan. }\end{array}$ & $\begin{array}{l}\text { Menyediakan } \\
\text { dukungan legal } \\
\text { terhada } \\
\text { pengembangan } \\
\text { institusi. } \\
\\
\text { Mencoba untuk mela- } \\
\text { kukan pilot-project. }\end{array}$ \\
\hline 4 & $\begin{array}{ll}\text { Kohesi kelompok.* } \\
\checkmark & \text { Masyarakat secara } \\
& \text { permanen tinggal di } \\
& \text { sekitar daerah yang akan } \\
& \text { dikelola. }\end{array}$ & $\begin{array}{l}\text { Sudah } \\
\text { teridentifikasi. }\end{array}$ & Sangat mungkin. & $\begin{array}{l}\text { Tidak ada } \\
\text { batasan. }\end{array}$ & \\
\hline & 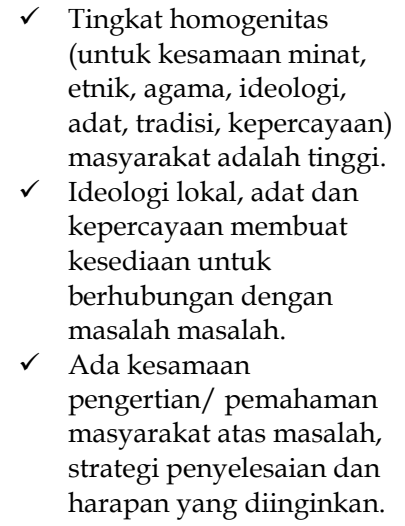 & $\begin{array}{l}\text { Sudah } \\
\text { teridentifikasi. }\end{array}$ & Sangat mungkin. & $\begin{array}{l}\text { Tidak ada } \\
\text { batasan. }\end{array}$ & \\
\hline 5 & $\begin{array}{cl}\text { Organisasi yang ada. } \\
\checkmark & \text { Masyarakat sudah paham } \\
& \text { tentang keberadaan } \\
& \text { organisasi yang terkait } \\
& \text { dalam pengelolaan } \\
& \text { sumberdaya perikanan. } \\
\checkmark & \text { Masyarakat sudah } \\
& \text { mempunyai pengalaman } \\
\text { sebelumnya dengan } \\
\text { pengelolaan perikanan } \\
\text { berbasis masyarakat dan } \\
\text { pengelolaan kemitraan } \\
\text { (co-management). } \\
\checkmark \quad \text { Identifikasi stakeholders } \\
\text { yang terkait dengan } \\
\text { sumberdaya perikanan. } \\
\checkmark \quad \text { Identifikasi seluruh } \\
\text { pengguna sumberdaya } \\
\text { beserta kepentingan } \\
\text { mereka masing-masing. }\end{array}$ & $\begin{array}{l}\text { Sedikit } \\
\text { teridentifikasi, baru } \\
\text { diimplementasikan } \\
\text { dibeberapa daerah } \\
\text { di Indonesia. } \\
\text { Tidak teridentifikasi. } \\
\text { Tidak teridentifikasi. }\end{array}$ & $\begin{array}{l}\text { Mungkin tapi } \\
\text { butuh sosialisasi } \\
\text { untuk } \\
\text { mengimplementas } \\
\text { ikannya dan } \\
\text { tergantung } \\
\text { dengan daerah } \\
\text { yang } \\
\text { bersangkutan, } \\
\text { daerah yang } \\
\text { sudah ada bentuk } \\
\text { pengelolaan } \\
\text { mempunyai } \\
\text { kemungkinan } \\
\text { yang lebih tinggi } \\
\text { dibanding daerah } \\
\text { yang tidak } \\
\text { mempunyai } \\
\text { bentuk } \\
\text { pengelolaan }\end{array}$ & $\begin{array}{l}\text { Tidak semua } \\
\text { daerah } \\
\text { mempunyai } \\
\text { bentuk } \\
\text { pengelolaan. }\end{array}$ & $\begin{array}{l}\text { Daerah yang tidak } \\
\text { mempunyai bentuk } \\
\text { pengelolaan, maka } \\
\text { model yang akan } \\
\text { diimplementasikan } \\
\text { harus sesuai dengan } \\
\text { kedekatan karak- } \\
\text { teristik mereka. }\end{array}$ \\
\hline
\end{tabular}


6 Fisibilitas ekonomi.

Masyarakat mempunyai

harapan bahwa manfaat dari

penerapan pengelolaan

sumberdaya perikanan

berbasis ekosistem dalam mengelola/memberdayakan sumberdaya yang ada adalah lebih besar dari pengorbanan (biaya investasi) yang harus dikeluarkan.

7 Partisipasi masyarakat/ pihak yang berkompeten.*

$\checkmark$ Seluruh masyarakat dan pihak yang berkompeten (pemerintah, swasta, akademisi, LSM) mempunyai tingkat partisipasi yang tinggi dalam pengelolaan sumberdaya perikanan sehingga sebagian besar atau bahkan seluruh masyarakat/ pihak berkompeten mempunyai akses untuk mempengaruhi pembuatan dan perubahan keputusan pengelolaan.

8 Aturan pengelolaan dijalankan secara efektif. ${ }^{*}$

$\checkmark$ Aturan-aturan yang digunakan dalam pendekatan berbasis ekosistem adalah sederhana, sehingga mudah dipahami oleh masyarakat.

$\checkmark$ Sistem pengawasan dan pelaksanaan dengan pendekatan ini lebih melekat, lebih efektif serta dengan biaya yang lebih murah dibanding dengan sistem pengawasan formal.
Sudah

teridentifikasi.

Mungkin

Tergantung kesiapsiagaan masyarakat untuk

mengim-

plementasikan model.

Tidak teridentifikasi Mungkin. semua.

Kebijakan atau peraturan tentang pengelolaan masih belum jelas, pendidikan masyarakat nelayan yang masih relatif rendah menyebabkan kurangnya insiatif untuk berpartisipasi.

$\begin{array}{ll}\text { Belum } & \text { Secara teori } \\ \text { teridentifikasi. } & \text { mungkin. }\end{array}$

Kesediaan masyarakat.
Memberikan penyuluhan kepada masyarakat.

Memberikan penyuluhan dan motivasi untuk berpartisipasi.

(n)




\begin{tabular}{|c|c|c|c|c|c|}
\hline \multirow[t]{3}{*}{9} & \multicolumn{5}{|l|}{$\begin{array}{l}\text { Legalitas untuk } \\
\text { berorganisasi.* }\end{array}$} \\
\hline & $\begin{array}{l}\text { Organisasi atau kelompok } \\
\text { mempunyai hak yang } \\
\text { legal untuk bisa menge- } \\
\text { lola dan membuat } \\
\text { peraturan secara formal } \\
\text { atau mandiri atas } \\
\text { sumberdaya yang ada. }\end{array}$ & $\begin{array}{l}\text { Sejauh ini belum ada } \\
\text { hak yang legal. }\end{array}$ & $\begin{array}{l}\text { Tergantung kepu- } \\
\text { tusan pemerintah } \\
\text { untuk } \\
\text { mendelegasikan } \\
\text { hak legal terhadap } \\
\text { organisasi atau } \\
\text { kelompok. }\end{array}$ & $\begin{array}{l}\text { Kepentingan } \\
\text { dan proses } \\
\text { politik, legali- } \\
\text { sasi, institusi } \\
\text { dan masalah } \\
\text { sosial } \\
\text { ekonomi. }\end{array}$ & $\begin{array}{l}\text { Menyediakan } \\
\text { dukungan legal; } \\
\text { politik dan hukum. }\end{array}$ \\
\hline & $\begin{array}{l}\text { Terdapat legalitas dari } \\
\text { pemerintah secara formal } \\
\text { untuk mendefinisikan } \\
\text { dan mengklarifikasikan } \\
\text { tanggung jawab lokal dan } \\
\text { wewenang dalam mene- } \\
\text { rapkan pengelolaan } \\
\text { sumberdaya perikanan } \\
\text { berbasis ekosistem. }\end{array}$ & $\begin{array}{l}\text { Belum } \\
\text { teridentifikasi } \\
\text { semua legalisasi } \\
\text { untuk pengelolaan } \\
\text { perikanan berbasis } \\
\text { ekosistem. }\end{array}$ & $\begin{array}{l}\text { Mungkin, sebenar- } \\
\text { nya untuk } \\
\text { provinsi Jawa } \\
\text { Tengah sudah ada } \\
\text { peraturan yang } \\
\text { mendukung yaitu } \\
\text { Perda Provinsi } \\
\text { Jawa Tengah } \\
\text { Nomor } 9 \text { Tahun } \\
2009 \text { tentang } \\
\text { pengelolaan } \\
\text { wilayah pesisir } \\
\text { dan pulau-pulau } \\
\text { kecil di Provinsi } \\
\text { Jawa Tengah. }\end{array}$ & $\begin{array}{l}\text { Kepentingan } \\
\text { dan proses } \\
\text { politik, legali- } \\
\text { sasi, institusi } \\
\text { dan masalah } \\
\text { sosial } \\
\text { ekonomi. }\end{array}$ & $\begin{array}{l}\text { Menyediakan } \\
\text { dukungan legal; } \\
\text { politik dan hukum. }\end{array}$ \\
\hline \multirow[t]{2}{*}{10} & $\begin{array}{l}\text { Kerjasama dan } \\
\text { kepemimpinan di tingkat } \\
\text { masyarakat.* }\end{array}$ & & & & \\
\hline & $\begin{array}{l}\text { Ada insentif dan } \\
\text { kemauan dari masyarakat } \\
\text { untuk berartisipasi aktif } \\
\text { (dalam hal waktu, upaya, } \\
\text { uang, dll) dalam } \\
\text { pengelolaan sumberdaya } \\
\text { perikanan. } \\
\text { Ada individu/ kelompok } \\
\text { utama/ daerah protokol } \\
\text { yang mempunyai } \\
\text { tanggung jawab untuk } \\
\text { memimpin dalam proses } \\
\text { pengelolaan. }\end{array}$ & $\begin{array}{l}\text { Belum } \\
\text { Teridentifikasi }\end{array}$ & Mungkin & $\begin{array}{l}\text { Pendidikan } \\
\text { masyarakat } \\
\text { nelayan yang } \\
\text { masih cende- } \\
\text { rung rendah }\end{array}$ & $\begin{array}{l}\text { Memberikan penyu- } \\
\text { luhan dan motivasi } \\
\text { untuk berpartisipasi. }\end{array}$ \\
\hline \multirow[t]{2}{*}{11} & $\begin{array}{l}\text { Desentralisasi dan } \\
\text { pendelegasian kewewenang.* }\end{array}$ & & & & \\
\hline & $\begin{array}{l}\text { Pemerintah telah membuat } \\
\text { kebijakan/ peraturan tentang } \\
\text { desentralisasi dari fungsi } \\
\text { administrasinya dan } \\
\text { pendelegasian tanggung } \\
\text { jawab pengelolaan dan atau } \\
\text { wewenang kepada } \\
\text { pemerintah daerah dan } \\
\text { organisasi lokal. }\end{array}$ & $\begin{array}{l}\text { Iya untuk } \\
\text { pemerintah daerah } \\
\text { tapi belum untuk } \\
\text { level kelompok atau } \\
\text { organisasi. }\end{array}$ & $\begin{array}{l}\text { Tidak mungkin } \\
\text { secara politik dan } \\
\text { hukum karena } \\
\text { Indonesia } \\
\text { mempunyai } \\
\text { kecenderungan } \\
\text { kepada } \\
\text { pemusatan } \\
\text { pemerintahan. }\end{array}$ & $\begin{array}{l}\text { Keinginan } \\
\text { politik dan } \\
\text { hukum. }\end{array}$ & $\begin{array}{l}\text { Menyediakan } \\
\text { dukungan hukum } \\
\text { untuk kewenangan. }\end{array}$ \\
\hline
\end{tabular}




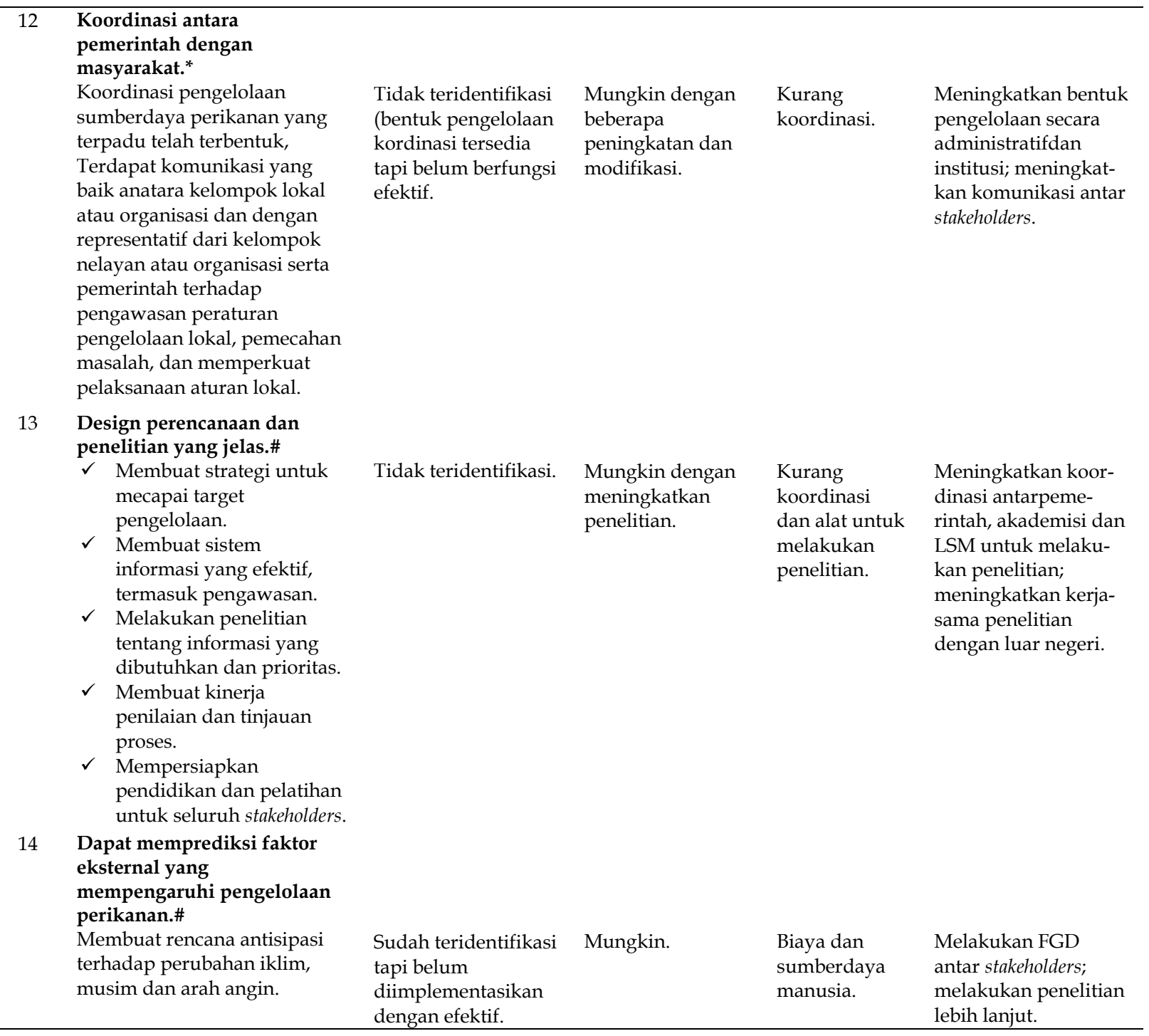

Kesimpulan: Pengelolaan sumberdaya perikanan berbasis ekosistem sebagai paradigma baru diprediksi dapat diterapkan di Indonesia, walaupun mungkin akan membutuhkan waktu yang lama untuk melihat keberhasilan model ini.

Sumber: *Ostrom (1990, 1992); Pinkerton (1989); dan Susilowati (1999) dengan modifikasi seperlunya (2012).

\# Grieve, Chris and Katherine Short., 2007 dengan modifikasi 